Portland State University

PDXScholar

\title{
A Cross-national Study of Attitudes and Group Labeling: Multinational Corporation (MNC) Workers in Canada, Brazil, and West Germany
}

Tobias Albert Ten Eyck

Portland State University

Follow this and additional works at: https://pdxscholar.library.pdx.edu/open_access_etds

Part of the International Relations Commons, and the Sociology Commons Let us know how access to this document benefits you.

\section{Recommended Citation}

Eyck, Tobias Albert Ten, "A Cross-national Study of Attitudes and Group Labeling: Multinational Corporation (MNC) Workers in Canada, Brazil, and West Germany" (1994). Dissertations and Theses. Paper 4840.

https://doi.org/10.15760/etd.6716

This Thesis is brought to you for free and open access. It has been accepted for inclusion in Dissertations and Theses by an authorized administrator of PDXScholar. Please contact us if we can make this document more accessible: pdxscholar@pdx.edu. 
The abstract and thesis of Tobias Albert Ten Eyck for the Master of Science degree in Sociology were presented August 3, 1994 and accepted by the thesis committee and the department.

COMMITTEE APPROVALS R. Kezly Hancock Chair

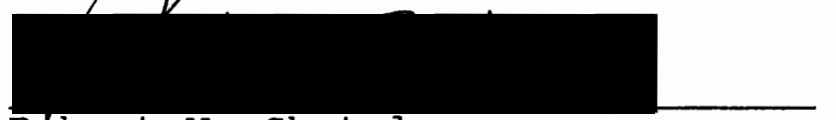

Róbert w. Shgtola

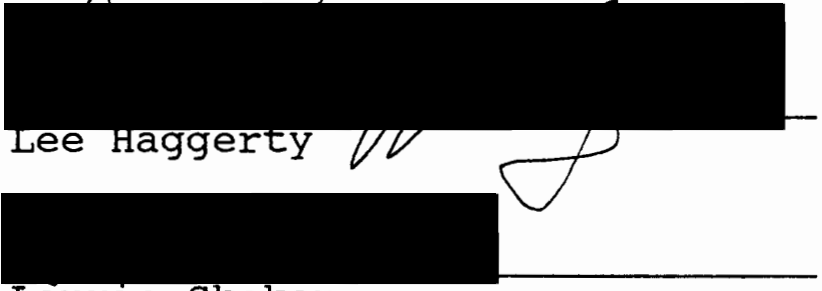

Laurie Skokan

Representative of the office of Graduate studies

DEPARTMENTAL APPROVAL:

Robert W. Shotola, Chair Department of Sociology

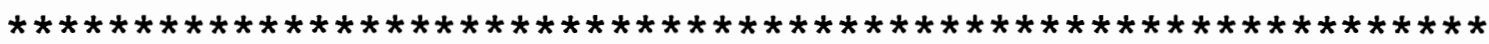
ACCEPTED FOR PORTLAND STATE UNIVERSITY BY THE LIBRARY by on

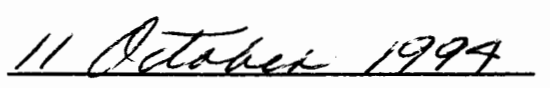


ABSTRACT

An abstract of the thesis of Tobias Albert Ten Eyck for the Master of Science in Sociology presented August 12, 1994.

Title: A Cross-national study of Attitudes and Group Labeling: Multinational corporation (MNC) workers in Canada, Brazil, and West Germany.

Many studies concerning multinational corporations (MNCs) are replete with theoretical models and case studies that treat MNCs as stand-alone entities. Very little time and effort is given to understanding the context in which MNCs operate. This context includes not only the fact that MNCs transcend national boundaries (political as well as geographical), but also the meaning of work and being part of a multinational work force for those employed within MNCs. This thesis is an effort to elucidate how the political/societal/cultural contexts of different host countries affect the attitudes of those workers most directly involved with foreign-owned MNCs. By shifting the focus from the MNC to the political/societal/cultural environment of host countries, foreign-owned MNCs can be compared across national boundaries (foreign-owned MNC workers from three different countries are compared in this 
thesis -- Canada, Brazil, and West Germany). Finally, by grounding the workers' attitudes within social identity theory, divergent attitudes between the workers from the different countries are not only explained, but expected as wel1. 
A CROSS-NATIONAL STUDY OF ATTITUDES AND GROUP LABELING: MULTINATIONAL CORPORATION (MNC) WORKERS IN CANADA, BRAZIL, AND WEST GERMANY

by

TOBIAS ALBERT TEN EYCK

A thesis submitted in partial fullfillment of the requirements for the degree of

\section{MASTER OF SCIENCE \\ in \\ SOCIOLOGY}

Portland State University

1994 
TABLE OF CONTENTS

PAGE

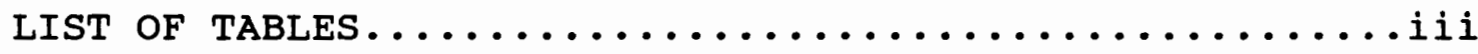

IIST OF FIGURES ..........................

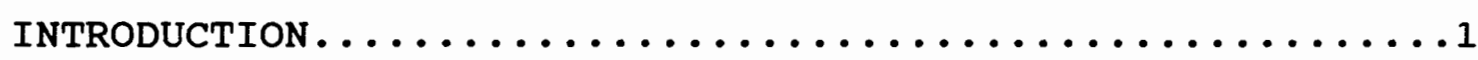

REVIEW OF LITERATURE.......................4

Group labeling/social identity theory

Work

Multinational Corporations (MNCs)

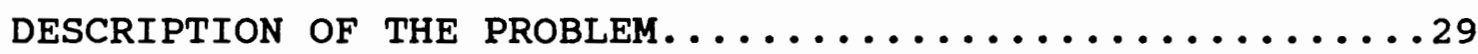

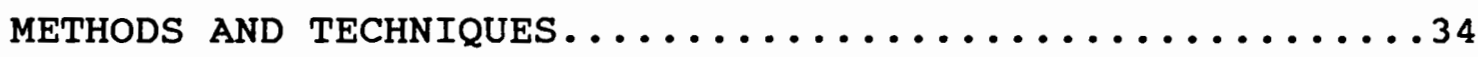

DATA ANALYSIS AND POSSIBLE DISCREPANCIES............44

Canada.................................. 45

General history

Politics

Military activities

Labor -- strikes and unemployment

Quebec

Quantitative data

Hypotheses, predictions, and data for Canadian workers

Brazil...............................66

General history

Politics

Military activities

Labor -- strikes and unemployment

Quantitative data

Hypotheses, predictions, and data for Brazilian workers

West Germany............................83

General history

Politics

Military activities 
Labor -- strikes and unemployment Quantitative data

Hypotheses, predictions, and data for West German managers

Possible Discrepancies........................104

CONCLUSION AND RECOMMENDATIONS FOR FURTHER STUDIES....106

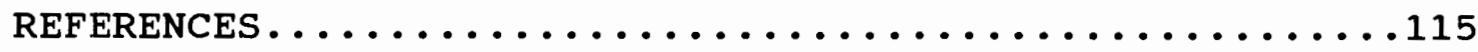




\section{LIST OF TABLES}

TABLE

PAGE

I U.S. Attitudes Towards Foreign Investment (1).25-26

II U.S. Attitudes Toward Foreign Investment (2) ...27

III U.S. Attitudes Toward Japanese..............28

IV GNP and GNP per Capita, Canada 1967-1971......60

V Unemployment Rates, Canada 1967-1971..........60

VI Number of Strikes and Workers Invovled, Canada

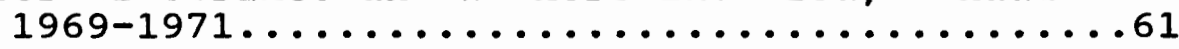

VII Workers' Overall Evaluation of MNCs in Canada...664

VIII GNP and GNP per Capita, Brazil 1970-1974......77

IX Unemployment Figures, Brazil 1970-1974........78

X Attitudes Toward Community Impact of Two U.S. Paper/Pulp Mills Operating in Brazil

(percentages)......................81

XI Positive Aspects of Companies' Effect on Community, Brazil (percentages)................81

XII Negative Aspects of Companies on Community, states

(of Brazil) or Brazil.................82

XIII GNP and GNP per Capita, West Germany 1972-1976..100

XIV Unemployment Rates, West Germany 1972-1976.....100

XV Strikes and Work Stoppages, West Germany 1972-1976

...........................101 


\section{LIST OF FIGURES}

1. Model of hypothesized interactions of independent variables on dependent variable.........42 
CHAPTER I

INTRODUCTION

It has been said that the world is shrinking and growing at the same time (Schermerhorn, 1978). Yet are the forces causing this polarization happening with equal strength? The world continues to grow (divide) through such events as the current conflicts in the republics of the former Soviet Union -- the most visible (to the Western World) being the armed conflict in and around Bosnia. There are other conflicts, such as those in Northern Ireland and Israel. Fighting has also erupted in Africa, though South Africa may be heading for peace. Cuba continues to be shut off from the U.S. (and much of the rest of the world), and the U.S. is forcing trade embargoes on Haiti and threatening them against Canada, Japan, and North Korea.

The world is also continuing to shrink as technology in the communication and transportation fields continues to grow. Travel to other countries is becoming cheaper and quicker, not only for national diplomats, but for the average citizen as well (though in many countries the price of long distance travel is still well out of reach for much of the population). Transoceanic business meetings are 
commonplace among large corporations, and faxes and modems are part of most offices.

The balance between these two forces, though, seems to be skewed to the former, at least as far as media coverage is concerned. National and ethnic conflicts make front page news, while technological innovations and transnational transactions are relegated to the back pages. Can the latter become more powerful than the former, or at least balanced? Do people really want to be part of a global community, or do they they have too much invested in national pride? By studying workers within foreign-owned multinational corporations (MNCs), I will not only try to make inroads into understanding these questions, but also look to gain a better understanding of group processes. For the latter endeavor, I will forsake the mainstream macro- and microsociological paradigms for a somewhat newer one: Social identity. The use of this theory constitutes a secondary purpose for this study.

studying workers' (or any human group's) attitudes is not an easy task. Theoretical work in this area is too aseptic to be used alone, while problems with direct observation (Hawthorne effect), and interviews and questionnaires (tendencies to give [perceived] socially correct answers) make empirical evidence tenuous, and findings must be used with caution. In addition, when studying the effects of specific institutions (in this case MNCs) on the attitudes of individuals, one should take into account other institutions that play a part in the observed 
attitudes. To overcome these shortfalls, I will combine existing empirical data on workers within foreign-owned MNCs with media accounts of national affairs and events in three different countries -- Canada, Brazil, and West Germany. This should alleviate some of the parsimony of studying attitudes and institutions separately, which in turn should give me a better insight into the formation of attitudes (loyalties?) of MNC workers when comparing the different countries. 
CHAPTER II

REVIEW OF THE LITERATURE

Many studies concerning groups and group processes have their roots in the university laboratory. Many college students have been assigned to groups through random selection, given some kind of task, and then had their response(s) recorded by some social science graduate student. These groups then dissipate with (usually) little or no contact between members after the experiment. These studies are then used to explain group processes outside the university (Paulus and Nagar in Hendrick (ed.), 1987). In other cases, "real world" small groups and small group processes are studied, and these findings are used to explain large group processes (e.g. see Bodenhausen, Gaelick, and Wyer's intriguing explanation of nationalism based on relationships between heterosexual couples, in Hendrick, 1987). Though these studies have been done with real people, and have been useful to some extent, the study of groups must be expanded beyond the walls of the university and small groups. ${ }^{1}$ Large group processes (such

$1_{\text {This }}$ is not to say that there are no studies exclusively concerned with large groups, for there are many of these. For example, many authors have written about social movements (e.g. civil rights). Many social movements, though, when compared to something such as 
as religious affiliation, team fans, nationalism) need to be studied as phenomena beyond the small group, and analyzed to further the understanding of how we label ourselves, and under what circumstances are some group labels more salient than others.

There are many groups that could be studied, such as church groups, military groups, social clubs, or athletic teams. I have decided to study work groups, 2 since work is so important to a person's self identification (Argyle, 1989). Another important aspect of a person's self identification is nationality. As a matter of fact, nationalism has been a major cause of war in the past few centuries (Seabury and Codevilla, 1989). To study the salience of cosmopolitan worker vs. nationalistic worker, I will investigate three multinational corporation (MNC) work groups: Ford Canada workers; Brazilian workers in two U.S.-owned paper/pulp mills operating in Brazil; and, West German managers employed in MNCs. Before I begin to compare and contrast these three groups, a review of three

nationalism are small in scale. Most writers who have written on the subject of nationalism look only at the ends, and not the means. In other words, they write on the relationship between nations and the power this label has over the people living within the national borders. There are two things wrong with this. First of all, nations, per se, do not have relationships -- representatives of the nations do. Second, how does a national label attract so many people? I hope to suggest answers to these questions within the body of the text.

2 I use the term "work groups" to refer not only to fellow workers, but also other workers employed by the same company or type of work operating in different countries. 
areas of research is in order. The areas are group labeling/social identity theory (with an emphasis on nationalism as a type of group label), the importance of work, and the impact of MNCs on home and host countries.

\section{Group Labeling/Social Identity Theory}

In-group/out-group distinctions can be found in the work of many social scientists. Though this topic began long before the work of Kant, it is interesting to note that Kant was one of the first social scientists to present the idea that humans have a natural tendency (need) to categorize things (Walsh, 1975). He did not write about human groups per se, but his ideas can easily be translated into the many human group categories that can be found today (e.g. ethnicity, sex, age, religion, nationalism) which we use to categorize ourselves and others.

Turning to the classical thinkers in sociology, group differentiation is very salient. For the early conflict theorists, such as Marx and Engels, and Weber, the focus was on group antagonisms (Freeman vs. Slave, Bourgeoisie vs. Proletariat, political groups or politisher Verband, and so on): for early functional theorists, such as comte and simmel, the focus was on the needs fulfilled by different groups (Aron, 1967; Collins, 1986; Hogg and Abrams, 1988; Marx and Engles, [1848] 1972; Thompson and Tunstall, 1971). The idea or notion of different groups can be found in most sociological work, though it is not always the focal point. The works of Goffman, Parsons, 
Homans, Dahrendorf, Mills, Habermas, and many other sociologists are replete with groups and group affiliation and differentiation. Groups are based on family (e.g. Simmel, [1922] 1955), the means of production (Marx and Engles, [1848] 1972), ethnicity (e.g. Rex and Mason, 1986; van den Berghe, 1981), sex (e.g. Morris, 1967), religion (e.g. Durkheim, 1971). Groups are also differentiated by nationality. It is this last categorization that is examined here.

To some writers, nationalism is not an issue. For example, in his typology of groups, simmel lists (in order of importance to the individual) family, work, and social class as the three most important "groups" ([1922] 1955). From an everyday, inductive standpoint, this type of reasoning makes sense. For example, suppose your name is John Smith, you are an auto mechanic, and consider yourself to be part of the U.S. working class. Within national (U.S.) boundaries, the former two 'labels' (name and work) would give you an idea of self and where you thought you stood in U.S. society. The latter label (U.S. citizen) would be taken for granted since it would be a common label for most people with whom you interact on an every day basis. Now, let us suppose that you are traveling in a foreign land and meet another John Smith, who is also an auto mechanic and considers himself to be part of his country's working class. How do you distinguish yourself from this other John Smith? Most likely by place of birth, i.e. nationality. In other words, nationality can be a 
very salient label under certain circumstances, ${ }^{3}$ and may even become a master label in times of international conflict.

Unfortunately for simmel, then, nationalism is a powerful group marker. To Weber, "...nationalism is simply [political] legitimacy carried to fervid levels" (Collins, 1968, pg. 155); or another definition:

Nationalism... involves loyalty to a politically distinct entity, membership in an elaborately organised and relatively populous social grouping, adherence to a formalised ideology, and performance or relatively stereotyped allegiance-expressing behavior (Meyer, 1985; pg. 8).

In other words, people will fight over national identity and threats to it. Fighting does not always have to be violent, though it often is. As noted above, seabury and Codevilla (1989) point out that "[n]ationalism is the most widespread excuse for war in our time" (pg. 220). Pfaff (1993) calls it "the most powerful political force in the Twentieth century" (pg. 13).

Why is nationalism so important to so many people? Before addressing this question, it is important to look at some theoretical perspectives that cover group formation and labeling. I will examine three such perspectives -sociobiology, exchange theory, and social identity theory.

In its simplest form, sociobiology explains social phenomenon through natural selection (Reynolds, Falger and, the U.S.

${ }^{3}$ For example, if you were to meet this same person in 
Vine, 1985). In human societies, this means that whatever humans do is based on inclusive fitness for the individual. In other words, human actions and interactions can be reduced to what our genes are telling us to do. Most sociobiologists would say this is a vulgar simplification of their theoretical paradigm, and point out that most who follow this theoretical slant see genetic make-up as only part of human behavior. Cultural influences also play a major role in actions and interactions (Reynolds, et. al. 1985). This is not the place to open up the debate on sociobiology, but keep in mind, as van den Berghe pointed out, "...there can be no doubt that biological forces shape and constrain patterns of human organizations" (Turner, 1991, pg. 167) .

Turning to the sociobiological explanation of human groups,

...sociobiologists would emphasize that prior investments into offspring within a genetic population will make common defence against non-members very economical and very likely (Meyer, 1985, pg. 82).

This kind of explanation seems to take as a priori just the opposite; i.e. non-members would gain by destroying this population. 4 This interpretation is supported by van der Dennen, who notes that

${ }^{4}$ It is not surprising, given this scenario, that sociobiology and game theory are very compatible. The idea of a common defense against what is supposedly a common aggressor equates to zero-sum games; whatever one group loses the other one gains (these gains could be absolute or relative). 
... an individual or a society may be better prepared to avoid destruction by aliens as a result of a generalised tendency to distrust, avoid, or reject foreign-seeming individuals (1985, pg. 8).

Other sociobiologists, such as Melotti (1985) share this same view point. Finally, sociobiologists point out that in-group/out-group distinctions are too universal to be culturally based, given the variation of cultures around the world; this tendency must be genetically based (Reynolds, et. al., 1985).

Homans' exchange theory (as interpreted by Turner, $1991^{5}$ ) refutes such functional interpretations of group selection. For Homans, the formation of groups is not based on genes, but on

the attainment of rewards and avoidance of punishments. Interaction becomes social behavior whereby the mutual actions of individuals have cost and reward implications for the parties to the interaction (Turner, 1991., pg. 323).

Also, groups are usually formed around a leader. This leader has more capital resources ${ }^{6}$ which he/she can use to motivate others (through rewards and/or punishments) to engage in activities that the leader sees as leading to the attainment of more capital resources. The carrying out of these activities (whether it is conquering a neighboring

${ }^{5}$ Turner differentiates between exchange behaviorism and structural exchange theory. The former is derived from the work of George C. Homans, while the latter is taken from Peter M. Blau.

6 'Capital resources' does not necessarily mean money. It could be land, food, weapons, etc.. The important thing is that one person (or a very small group) has more than those around him/her (them). 
tribe or starting a business) leads to social organization. If the group is successful (either by increased rewards or avoiding punishments) it may become more efficient and further elaborate its patterns of organization. An important element of this theory is that it is grounded in social structures (networks), and so relations can be studied outside of bloodlines.

The third perspective is social identity theory. Social identity theory approaches group formation through investments in "positively valued distinctiveness from other groups to provide their members with a positive social identity" (Hogg and Abrams, 1988, pg. X). Unlike sociobiology, where genes are major determinants in human action and interaction creating a deterministic shading to the paradigm, social identity sees social categories as constantly in a state of flux due to economics and history. This does not mean that people easily redefine group boundaries. Since people use group membership as a source for positive identification (self-esteem), they will not readily reject current in-groups for possible future outgroups; there is too much at stake. Not only is positive self-identification at stake, but so is a person's (or group's) notion of order:

The theory of social identity rests on an assumption that categorization is the process by which people order, and render predictable, information about the world in which they live. This process of categorization operates on objects, other people, and oneself, and consequently people are seen as belonging to the same or different categories as oneself. Partly because the categorization involves a simplification and clarification of perception, and 
partly because there is a motivation to positively value the self, differentiation between one's own and other category members is often extreme, and biased in favour of the ingroup. These factors account for the existence of social competition and for the rigid and derogatory stereotypes held of outgroups (Hogg and Abrams, 1988, pg. 209).

Not only have these authors pointed out the importance of group membership to the social and psychological order in a person's life, but also the existence of stereotypes.

The idea of a constant flux in social categories, though, may provide an important insight into modern society and multinational corporations. Transnational practices of multinational corporations bring about contact with foreign influences, though contact is not sufficient to bring about a reduction in intergroup hostilities (Hogg and Abrams, 1988). This contact with foreign influences, though, may have the ability to bring about social change (Hancock, 1980), and, according to social identity theory, "social-change beliefs may contribute both to the maintenance and to the alteration of the status quo..." (Hogg and Abrams, 1988, pg. 210). This may seem to be irrefutable, since a force either changes or does not change that which it comes up against, but on closer inspection of this idea one sees that maintenance of the status quo may actually mean a retrenching of traditional values; so, in a sense, maintenance of the status quo may actually be change of some kind. In other words, if the superordinate group (the in-group) is confronted by a subordinate group (the out-group) and it does not accept the latter, its status quo will not be changed to the 
outside observer, but may have actually become even more adamant about its own values and beliefs. 7 Also, the subordinate group can expect resistance if it does not back away from its confrontation with the superordinate group. The above summaries do little justice to the breadth and depth of these three theoretical perspectives and the literature on group formation as a whole (of which there are many more theories). These three were chosen for their differences and contrasts. Each one has its strengths and weaknesses. Sociobiology addresses the existence of strong family and clan ties, but theories based on genetic ties are hard to expand to groups based on nationality (though their authors try). Exchange theory (the type discussed here) is good for small groups with little or no blood ties, but once again, this theoretical model is stretched when used to explain the existence of nationalism. 8 Also,

${ }^{7}$ A group does not have to confront another group to futher entrench its beliefs and values. Take the example of the Doomsday cult and its failure to predict the end of the world. Instead of giving up their beliefs when the end did not come, they became more unrelenting in their beliefs, saying their unwavering faith was the reason the earth had been spared (Lofland, 1977).

8 There have been some authors that have used exchange theory to explain macroprocesses, namely Richard Emerson (Cook, 1987; Turner, 1991). Unfortunately his work in this field is concerned mainly with relations between nations, which sheds little light on the reasons why a large number of people would choose a nation as part of their identity. Also, by looking at the relations between nations, I think that Emerson has taken a macroprocess which involves many people (or more specifically their representatives) and turned it into a reified microprocess concerning pieces of land. 
exchange theorists admit that their theory does not adequately explain the specific circumstances in which coalitions form (Gillmore in Cook, 1987). It is only social identity theory that can adequately explain both small groups (with or without blood ties), as well as large groups such as those centered around nationality.

Since social identity is the theory of choice for me, the question as to why nationality is so important to so many people can now be addressed. Take an hypothetical situation, one that is familiar to the reader. A person is traveling outside of his/her native country and meets a stranger from yet another country. It so happens that they both speak the same language, do the same kind of work, share the same ethnic backgrounds, are the same age and sex, and enjoy the same hobbies. So what is different about these two people? Their nationality. From a social identity perspective, this could be enough for them to cast the other as an out-group member, especially if these people are in need of some positive self value, or their respective countries are in some kind of conflict. It is not improbable that such meetings could happen. ${ }^{9}$ Nationalism of this sort is not confined just to citizens of the U.S. Forbes (1985) noted sociological and psychological studies measuring nationalism could be found

${ }^{9}$ For example, citizens from the U.S. and Canada could meet in a third country (such as Mexico or Germany). It is also not unlikely that the only difference that these people would have would be their nationality. 
in articles from South Africa, Australia, Belgium, France, Germany, Italy, Netherlands, England, Wales, Sweden, Lebanon, Tahiti, The Cook Islands, Samoa, and Canada. Exactly how many people are nationalistic is hard to measure, since nationalism is not only an ambiguous term (even given the definitions mentioned above), 10 but also because people tend to vary in the amount of nationalism they espouse depending on both psychological dispositions and social situations (Adorno, Frenkel-Brunswik, Levinson, and Sanford, 1950). Still, given the amount of time and effort spent on the study of nationalism (both directly and indirectly) it should be clear that it plays a major role in group formation. 11 Recent world events, such as the fighting in Bosnia and the debate over the North American Free Trade Act (NAFTA), have also shown the salience (and importance) of nationality. 12

10 Forbes notes that nationalism falls somewhere between patriotism and xenophobia. For the native, this is the difference between rational and irrational love for one's country; for the foreigner, both are indications of an unwillingness to accept new people.

${ }^{11}$ According to the Social science Index, 90 articles dealing with the subject of nationalism were published in academic journals between April 1992 and March 1993 (Ehrens, 1993). (A quick review of other works on this subject includes Barclay, 1972; Benson, 1992; Burg, 1993; Cornelius, 1993; Deutsch, 1969; Friedman, 1992; Garvey, 1992; Gelb, 1991; Hoagland, 1992; Hobsbawm, 1991; Joffe, 1990; Keatley, 1991; Kedourie, 1961; Kis, 1992; Ladd, 1986; Leone, 1986; Lewis, 1992; Manning, 1992; Meadwell, 1989; Pilon, 1992; Schrage, 1992; Shafer, 1955; Walzer, 1993; Ward, 1966.)

12 Some may argue that the fighting in the former Yugoslavia is not about nationality but about ethnicity, but I would argue that the groups were fighting for the 
Work

Work has to be done.... It has to be done to provide food, clothes, shelter, protection from enemies without and disruptive elements within, care, protection, and education of children, and all the elaborate arrangements for entertainment, travel, etc. to which we have been accustomed (Argyle, 1989).

This passage points to the fact that for basic survival purposes, most humans have to work. There are very few individuals that can escape this reality, to the point that their basic survival needs are met with no effort of their own. ${ }^{13}$ Work is not only essential to meet basic survival needs, but may even be necessary for mental health ${ }^{14}$ (Argyle, 1989), as well as for creating new value in a capitalist society ${ }^{15}$ (Wolff, 1984) and a sign from God for the redemption of the soul (Aron, 1968).

right to have their own state. The NAFTA debates, though centered around jobs, became a strong anti-Mexico rallying point for some strong U.S. and Canadian nationalists.

${ }^{13}$ The majority of those in this position are severly handicapped, and it could be argued that basic activities such as eating and elimination require considerable efforts on their parts.

${ }^{14}$ This idea of the need to work for mental health reasons may be the motivation for people to continue to work even when it is not financially necessary. Argyle (1989) noted that surveys dealing with such issues found well over 50 percent of the people who took part in the surveys would continue to work, though some would look for different employment. (There is a line of argument that work is loathsome, contradictory to Argyle's stance. This argument is based on some of Freud's works. See Tausky, 1992).

${ }^{15}$ From a Marxist standpoint, this means that not only is work important to the proletariat (for a number of reasons, including class consciousness and creativity), but also to the bourgeoisie, who can only create new value through surplus labor power. 
The idea that work is important not only to feed and cloth a person (and possibly his/her family), but also for mental health reasons makes it a prime candidate for another category on which to base self-identification as well as group affiliation. Marx and Engles thought that workers in all countries should be part of one group ([1846] 1972), 16 while others saw workers divided among themselves based on occupational (and industry) status (Crozier and Friedberg, 1980; Prezeworski and Sprague, 1986).17

Whether workers see themselves as comprising a worldwide class, or as smaller occupational groups, there is sufficient evidence that work (or what one does for a living) has a strong effect on individual personality and larger components of society. For example, Kohn (1990) stated that "the effect of job conditions on personality are far from trivial in magnitude..." (pg. 40). According

${ }^{16}$ This idea is captured in the famous last line of Marx and Engles' Communist Manifesto: Workingmen of all countries, unite! ([1846] 1972, pg. 116). Marx and Engles' idea of two separate classes in capitalist societies (bourgeoisie and proletariat) is further emphasized by other Marxists, such as Disraeli who termed these two groups as two separate nations (Bottomore in Chambliss, 1973).

${ }^{17}$ Some industries hold a higher status than others. For example, to be an engineer in the areospace industry is likely to carry more status than being an engineer in a small tool shop, though both may require the same skills. Also, some companies carry more status than others. In the Pacific Northwest, the occupational title of Boeing Engineer will usually carry more status than, say, Red Ball Engineer. 
to Thompson (1983), "[w]ork has always been necessary to satisfy the various social needs that exist in human society" (pg. 38). Marx and Engles ([1846] 1970) stated that "[men] begin to distinguish themselves from animals as soon as they begin to produce their means of subsistence..." (pg. 42, emphasis in the original). Even in his utopian (communist/socialist) society, Marx pointed out that labor would be a first need of life (Zdravomyslov, Rozhin, and Iadov, 1970). When a GE plant in ontario, CA. closed down, a typical response of the displaced workers was the feeling that one had lost a family member (Haas, $1985)$.

Sociologists interested in split labor market theory anchor their theory on the struggles between workers (with differences between workers usually based on race) which stem from the workers' fierce loyalties to their work (e.g. Bonacich in Pettigrew, 1980). One of the foremost writers on humans and their work, the late Everett $c$. Hughes, pointed out that it is not only self-identification that stems from what one does for a living, but also how others in society identify individuals:

... a man's work is one of the things by which he is judged, and certainly one of the more significant things by which he judges himself (pg. 42).

Many people in our society work in named occupations. The names are a combination of price tag and calling card (pg. 42$)$.

...a man's work is one of the more important parts of his social identity, of his self; indeed, of his fate in the one life he has to live, for there is something almost as irrevocable about choice of occupation as there is about choice of mate (pg. 43). 
...the language about work is...loaded with value and prestige judgments... (pg. 43 ).

These general statements are backed by a number of studies done on the unemployed. Argyle (1989) summarized some of these studies, and reached the following conclusions:

General emotional disturbance is lower for those at work than for all categories of unemployed.... (pg. 291, emphasis in original).

Depression is usually found to be higher among the unemployed (pg. 292, emphasis in original).

Suicide is more common among the unemployed (pg. 293 emphasis in original).

and

There is no question that the unemployed are in poorer health than the employed (pg. 293).

All of the above statements make it clear that humans need to work for self-fulfillment, and that it has a powerful influence on our lives. ${ }^{18}$ This account of the importance of work could be extended, but little would be gained from such an extension. What is important here is to note that people will not easily quit work, as it meets the needs not only for basic survival, but also for positive self values. 19 In other words, when people quit working (other than through retirement) it is usually due

${ }^{18}$ It is important to note that our non-work lives also have a powerful influence over our work (Kohn, 1990).

${ }^{19}$ Argyle points to the fact that even people in low status occupations will use this occupation to put themselves above groups such as the unemployed ("At least I have a job.") (1989). 
to extreme circumstances (Mueller, Wallace, and Price, 1992 ).

\section{Multinational Corporations (MNCs)}

The multinational corporation (MNC) is interesting sociologically because it is a place where the importance of nationalism and work are combined. It is a place where a researcher can test the power of the group label "nationalist worker" against the group label "cosmopolitian worker," and see which, if any, is more salient to nativeborn workers.

There are few, if any, nations that have not been affected by MNCs, both as home and host nations. The actual impact of MNCs on any country is hard to measure. For example, in 1989 in the U.S., 88,938 foreign-owned affiliates reported employing a total of 4,734,500 people. The $1991^{20}$ statistics showed an increase of two percent to $4,809,200$ employees working for foreign-owned firms in the U.S.. This accounted for 5.2 percent of the U.S. labor force. (U.S.-Owned MNCs accounted for an even greater number of employees in the U.S. ${ }^{21}$ ) Average wage compensation for foreign-owned firms operating in the U.S.

20 The 1991 statistics reported were for foreign-owned nonbank U.S. affiliates.

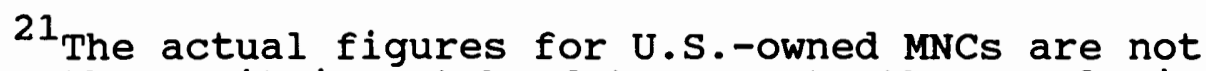
known, though it is not hard to come to the conclusion that these firms employ more U.S. citizens than foreign-owned firms, based on the number of U.S.-owned MNCs versus foreign-owned MNCs. 
in 1991 was reported to be $\$ 36,200,26$ percent higher than U.S. firms (Bezirganian, 1993). The total amount of U.S. direct investment abroad is estimated at $\$ 776.3$ billion (market cost), while the three largest foreign investors in the U.S. (Japan, 22 the United Kingdom, and the Netherlands) accounted for $\$ 252.7$ billion (Scholl, Lowe, and Bargas, 1993). The U.S. is (at this time) the largest home and host nation for MNCs, but other nations also have large investments in MNCs, including Canada and West Germany (two countries examined in this study).

These statistics, though impressive to those who read them, do not influence workers as much as popular literature. In the U.S. and other nations, headlines, Best Sellers, and magazine and newspaper articles carry the stories seen and read by many people. The stories concerning MNCs vary from high enthusiasm to dark pessimism, which means readers may be getting mixed signals, unless one viewpoint is more prevalent than the other. The following is a summary of the typical stories found in U.S. popular literature.

Arguably, the most salient aspect of MNCs is their effect on employment (Nicolaides, 1991). ${ }^{23}$ In their best selling book, The New Competitors, Glickman and Woodward (1989) argued that between 1977 and 1986, U.S.-owned MNCs

${ }^{22} \mathrm{Nineteen-ninety-two} \mathrm{was} \mathrm{the} \mathrm{first} \mathrm{year} \mathrm{Japan} \mathrm{held}$ the largest position of foreign investment in the U.S.. ${ }^{23}$ This is true for most countries, not just the U.S. 
accounted for a loss of 2.7 million jobs, while foreignowned MNCs resulted in a net loss of 55,863 jobs between 1982 and 1986.24 The fear of loss of jobs is also the rallying cry for many opponents of the North American Free Trade Agreement (NAFTA) (MCGinn and Moody, 1993; Rothstein, 1991). Newspapers and magazines with wide readerships such as The Christian Science Monitor, The Washington Post, The Wall Street Journal, and Fortune, 25 have carried numerous articles on the detrimental effect on employment of U.S.based MNCs. At the same time, these same newspapers and magazines have also run articles stressing the importance of both foreign-based and U.S.-based MNCs in creating jobs. 26 These arguments are compounded by a third viewpoint, in which MNCs have a net effect close to zero

${ }^{24}$ This loss, according to Glickman and Woodward, can be attributed to a number of factors, including downsizing and the fact that foreign-owned MNCs are many times vertically integrated in the home country.

${ }^{25}$ These newspapers and magazines themselves may not be read by many working class people, but the stories carried in these publications are copied in many other local newspapers around the nation.

${ }^{26}$ For example, compare the following headlines: From The Wall Street Journal -- "New Studies Refute Fears of Foreign Investment" (October 1, 1991, pg. A22) vs. "Overseas Calling: American firms send office workers abroad to use cheaper labor" (August 14, 1991, pg. A1); or The Oregonian -- "Pickets Protest Foreign Cars" (with an accompany story regarding the picketers fears of job exports) (February 11, 1192, pg. D6) vs. "North American Free Trade Talks: Boon or bane?" (with an accompanying story of how NAFTA will create numerous jobs in oregon) (January 25, 1993, pg. D7) . 
(Graham and Krugman, 1991).27

Another salient issue with MNCs is that of national security (and the transfer of technology). ${ }^{28}$ Should foreign-based firms be allowed to buy (in this case) U.S. high-tech companies such as aerospace and weapons companies? Again, there is little consensus in the popular literature. Ohmae, in his best seller The Borderless World (1990), promotes the idea that companies (and nations) can no longer think in terms of national boundaries when dealing in the global economy. This viewpoint can be contrasted with articles carried by The New York Times (Bradsher, 1993; Zakheim, 1990), Los Angeles Times (1992), and Time Magazine (Van Voorst, 1992). These latter articles are filled with stories of how the U.S. is selling

${ }^{27}$ Graham and Krugman base their findings on the macroeconomics of employment determined by supply, not demand. In their own words:

Suppose, for example, that a wave of FDI [foreign direct investment] into the United States turned out to have a substantial immediate positive effect on demand for US workers. The normal response of the Federal Reserve would be to tighten monetary policy to avoid accelerating inflation, so that any job gains resulting from the investment would be offset by job losses elsewhere. Conversely, a wave of investment that had a negative impact of the demand for labor would be met by looser monetary policy and thus be offset by job gains elsewhere (pg. 61).

This kind of argument can be also be applied to outgoing FDI. the U.S.

28 once again, this concern is not relegated to just 
off its ability to defend itself; that it will soon be an easy target for attack.

The ability of MNCs to evade taxes also receives plenty of attention in popular books, newspapers, and magazines. Glickman and Woodward point out that many foreign-owned firms know that states will bid for them, and one of the bargaining chips is that of tax breaks (1989). Articles in the leading national newspapers and magazines have also touched on the evasive powers of both foreignbased and U.S.-based MNCs when it comes to paying taxes (Gleckman, 1990; Heins, 1986; Hilzenrath, 1993; Martz, 1991; McIntyre, 1989; Moskowitz, 1991).

These are not the only issues raised by the popular literature in regard to MNCs. 29 The overall power of MNCs is frequently cited (Brannigan, 1990; Grieder, 1992; Piel, 1992). The recent sale of the Seattle Mariners to Japanese investors (Ninetendo) caused a stir in professional baseba11. MNCs vs. anti-trust laws are also part of the literature, as are social policies (should MNCs be concerned with host countries' problems?). Each of these issues has both its opponents and proponents. This makes it extremely difficult to say where most readers would stand on these issues (and the issue of MNCs in general)

${ }^{29}$ A popular fictional book and movie that was released at the time of this study was Michael Crichton's Rising Sun (the book was published in 1992). The statement that "business is war" sums up the crighton's depiction of Japanese businessmen, evoking images of Pearl Harbor and World War II. 
without some kind of survey. Fortunately there have been some surveys on this matter.

One was done in 1988 by Smick-Medley and associates and the results were reported in the 1988 May/June issue of The International Economy (U.S. attitudes toward foreign investment, 1988). Respondents to this survey were categorized into two groups -- Masses and Elites. Elites consisted of people such as Congressmen, mayors, and corporate leaders, and Masses are all those who are not part of at least one of the above categories, in other words, ordinary "working class" people. Approximately 100 Elites and 900 members of the working class took part in this survey. Both the questions and results of the survey are shown in TABLE $I$.

\section{TABLE I}

U.S. ATTITUDES TOWARD FOREIGN INVESTMENT (1) 30

\section{Foreign Investors:}

can cause a financial crisis by withdrawing their money from U.S. banks

Might pull their money out at any time

Have more influence in our national government

Cause Americans to have less control over our economy

\begin{tabular}{llll}
\multicolumn{2}{c}{ Masses ( $\left(\frac{\%}{)}\right)$} & \multicolumn{2}{c}{ Elites (\%) } \\
Yes No DK & Yes No DK
\end{tabular}

$$
80
$$

7

75

21

4

55

41

3

7

$\begin{array}{lllll}22 & 3 & 39 & 58 & 3\end{array}$

${ }^{30}$ source for TABLES I and II, U.S. attitudes toward foreign investment, 1988. DK = Don't know. 
TABLE I

U.S. ATTITUDES TOWARD FOREIGN INVESTMENT (1) (continued)

Yes Masses (\%) No DK Ylites (\%)

If Foreigners Owned Your Bank:

would you get higher rates

on your account?

$\begin{array}{llllll}17 & 61 & 22 & 4 & 80 & 15\end{array}$

Would it affect your ability

to get a loan?

$\begin{array}{llllll}23 & 61 & 16 & 4 & 82 & 14\end{array}$

Would it jeopardize the safety

$\begin{array}{llllllll}\text { of your savings account? } & 41 & 45 & 14 & 3 & 90 & 7\end{array}$

What to Do About Foreign Investment:

Prohibit any further

investment

$\begin{array}{llllll}40 & 54 & 6 & 1 & 99 & 0\end{array}$

Register foreign investors

$\begin{array}{llllll}89 & 8 & 3 & 48 & 45 & 8\end{array}$

Limit foreign investment in

the U.S.

$\begin{array}{llllll}78 & 18 & 4 & 13 & 86 & 1\end{array}$

Encourage joint ventures

$\begin{array}{llllll}69 & 25 & 6 & 70 & 25 & 6\end{array}$

Give tax breaks to foreign

investors

$\begin{array}{llllll}21 & 75 & 4 & 52 & 40 & 8\end{array}$

These survey results show that there is no one set of ideas about MNCs in the U.S., and that there is a large differential between Elites and Masses. 31 This is further supported by the last question asked in the survey, which can be found in TABLE II (page 27).

As can be seen, the numbers show the disparity between the Masses and the Elites. Marx would probably have found

${ }^{31}$ And, of course, there is no 'pure' consensus within these groups. 
TABLE II

U.S. ATTITUDES TOWARD FOREIGN INVESTMENT (2)

$\begin{array}{lcc}\text { If foreigners bought the firm } & \text { Masses }(\%) & \text { Elites }(\%) \\ \text { you work for would you: } & & \\ \text { Resign } & 6 & 9 \\ \text { Organize resistance } & 25 & 0 \\ \text { Write to Congress } & 26 & 1 \\ \text { Support Legislation } & 4 & 37 \\ \text { Support foreigners } & 16 & 25^{32} \\ \text { Do nothing } & 7 & \end{array}$

these findings unsurprising. 33

The second survey was a New York Times/CBS News Poll, which appeared in The New York Times on July 10, 1990 (Oreskes, 1990). It differed in two ways from the smickMedley survey: Respondents were not categorized in any way, and questions were asked only about Japan's investment in the U.S. One thousand-eighty-four people were asked to respond to a series of statements, two of which are shown below (TABLE III, page 28), accompanied with the percentage of the people who answered "yes" to the statements. People who took part in this survey said that they were beginning to fear Japanese economic might more so than

32 The total percentages of both groups do not equal 100 percent, but 84 percent for the Masses and 72 percent for the Elites. It can only be assumed that the numbers were copied wrong, or a category was left out of the final report (such as a "Don't know" category).

${ }^{33}$ These findings are not universally accepted. Partner (1992) says that the fear of foreigners (specifically the fear of Japanese) goes beyond "the man on the street." One of the phobias he discusses is Japanese neo-colonialism that seems to affect people in both categories. 
TABLE III

U.S. ATTITUDES TOWARDS JAPANESE

Statement

Japanese compete unfairly in business

Most Americans look down on Japanese
\% of "yes" answers

38

$47^{34}$

Soviet military power.

These surveys, though, leave many stories untold. How do the people who are directly affected (i.e., the workers within the MNCs) feel about the role of MNCs? It may be that a large percentage of U.S. citizens are fearful of foreign investors (and of foreigners taking jobs away from U.S. workers), but, if this is true, does it hold for U.S. workers employed within these entities? What about other countries? For example, the three countries that will be examined in this study have all been home and host countries to MNCs. Will their workers embrace or eschew foreign direct investment? In the following chapter (Chapter Three) I will discuss this problem in more detail, as well as formulate my main hypothesis. Chapter Four will deal with methods of data retrieval.

${ }^{34}$ When the pollsters posed this same statement to Japanese about their attitudes towards Americans, 48 percent answered "yes." 


\section{DESCRIPTION OF THE PROBLEM}

The preceding chapter made it clear that the worker within the multinational corporation is worthy of study. MNCs are one of the few social institutions that cross national boundaries. The other two types of social institutions that typically crossover international borders are national governments and voluntary organizations. ${ }^{1}$ The former, though not necessarily violent, usually brings with it strong feelings of nationalism on the parts of both the host and home countries involved. This may be obvious in the case of an invading army, ${ }^{2}$ but this is also generally true of embassies and visiting governmental dignitaries. since nationalism is a strong motivational device for labeling in- and out-group members, this makes any kind of national governmental body an unlikely harbinger of welcomed social change. ${ }^{3}$ The latter, voluntary

$I_{\text {This }}$ leaves out individuals and small groups such as tourists. Such individuals and small groups are not considered social institutions. I also leave out the United Nations, since it is still trying to adapt to its transnational role.

${ }^{2}$ This has also been the case with most United Nation peacekeeping operations.

${ }^{3}$ This is clearly visible in third party "Peace Talks." Even a neutral nation can be seen as taking sides with one 
organizations, are too varied in nature to generalize from one kind to another (e.g. Peace Corps vs. The Jesuits; these two groups are both voluntary groups with international linkages, but their goals are not the same). MNCs, on the other hand, do have two things in common -the search for profits, and they employ foreign workers at some point in their operations. This makes it possible to compare across companies from different countries, operating in different countries, and engaged in many different areas of production.

The fact that MNCs employ foreign workers does not mean that all individual workers are the same, even if all worked for MNCs. Kohn (1991) points out 14 different aspects of work that can affect workers' attitudes toward their jobs. 4 Aspects of work such as average number of hours worked per week and dirtiness of the job are not the same in all MNCs. Someone working for an international bank is probably not going to have the same feelings toward work as someone who works for an international ditch digging company. Work conditions and individual workers' perspectives of work conditions are not going to be

party or the other, and this can even be a criticism from both sides!

${ }^{4}$ These fourteen aspects are ownership, bureaucratization, hierarchial position, substantive complexity of work, closeness of supervision, degree of routinization, time pressure, heaviness, dirtiness, the number of hours worked in the average week, being held responsible for things outside one's control, risk of losing one's job, job protections, and job income. 
comparable across MNCs, but what about the overall attitudes of workers toward MNCs? Is it true, as Maxcy (1981) put it, that economic man (hereafter referred to as "economic person") has no nationality?" 5 Can MNC workers be considered as economic persons, or only the capitalists who are the driving force behind MNCs? ${ }^{6}$

The idea that workers may not be classified as "economic persons" forms the basis for my main hypothesis. True economic persons would be indifferent to the national currency of profits or paychecks. If workers are true economic persons, their only concern would be that they receive fair pay (or some other kind of compensation) for fair work. Since many foreign-owned MNCs pay higher wages than both indigenous MNCs and domestic businesses, this would seem to be even more of an incentive for workers to welcome these companies. Therefore, my main hypothesis is as follows:

- If a person is employed within a foreign-owned MNC, then he/she will have a positive attitude towards foreign-owned MNCs (or at least a more positive

5 This idea is supported by Frank (1980). The CEOs in his study were very adamant about the home country government staying out of their business dealings in host countries. See also Chapter Five in Maxcy's book on the automobile MNCs' interests during World War Two.

6The 'driving force' mentioned here is not to be confused with the labor power that generates the products and/or services provided by the MNCs -- that comes from the workers. The 'driving force' generated by the capitalists is the search for profits that transends national boundaries. 
attitude when compared to those not employed by foreign-owned MNCs).

But, as seen in the last chapter, nationalism is a strong group label. Is it strong enough to override well paying work? By hypothesizing that the workers' way of life will be satisfied by the foreign-owned MNC, a null hypothesis would point out that either foreign-owned MNCs do not satisfy workers' expectations for adequate wages (and other work variables such as safety and benefits) or that workers are not economic persons, and that nationalistic pride has given them reason to find fault with foreign-owned MNCs (and possibly home-based MNCs as well). If the former is true, then possibly the MNCs could gain worker loyalty through higher wages (and/or added benefits). If the latter is true, there is little foreignowned MNCs can do to convince native workers to welcome them, and they will have to continually fight to win the loyalties of these workers (possibly by trying to win the favor of national leaders). If the hypothesis turns out to be supported in each case under study, then it is quite possible that MNC workers are truly economic persons. Either way, the study of large group label formation, as well as social identity theory, will have been taken a small step forward.

To test the above hypothesis, it will be necessary to construct a nationalistic structure of each country being studied. Measuring the workers' attitudes with only quantitative scales paints only half of a picture. What is 
still needed is a national context in which to place such findings. This is the only way to present a solid (though still incomplete) ${ }^{7}$ foundation of the workers' life experiences in regard to foreign direct investment at the time of the studies. In the next chapter, I will discuss those aspects that will be included in this study, the logic behind my choices, and the data which will be used.

7 This incompleteness comes from not knowing the individuals' total life experiences. Age, education, family views, and so forth would play some part in a person's attitudes in most, if not all, areas. All I can hope to do is understand those aspects that are readily available to the outside observer. 
CHAPTER IV

METHODS AND TECHNIQUES

Quantitative data have already been collected and analyzed for MNC workers' attitudes (the dependent variable in this study) in the three countries that I will be studying -- Canada, Brazil, and West Germany. Marton questioned Canadian workers employed by Ford Canada in 1971; Blake and Driscoll reported survey results from Brazilian workers employed by two U.S.-owned paper/pulp mills in 1974,1 and Sauvant and Mennis studied German workers within West German MNCs in 1976 (both foreign- and domestic-owned). ${ }^{2}$ what is missing is a larger (national) context in which these studies can be set and examined more closely.

Through available materials (such as the New York Times Index, government documents, books, and periodicals), a nationalistic structure (context) will be constructed for each country. There could be many variables within a national context that could affect workers' attitudes

${ }^{1}$ A Brazilian research firm -- Demanda Instituto de Pesquisas e Estudos de Mercado Ltda. -- administered the actual questionnaires. $(1982)$.

${ }^{2}$ All of the above studies can be found in Fayerweather 
toward MNCs. $^{3}$ I will confine my study to six that generally get media coverage (or influence it), and, therefore, would be easily accessible to the work force of a country. ${ }^{4}$ The six independent variables will include: (1) national political leaders' attitudes toward foreign investment and aid (both inward and outward), (2) military activities involving each country (once again, both inward and outward), (3) strikes and/or worker unrest within the countries, (4) Gross National Product (GNP), (5) GNP per capita, and (6) unemployment statistics. 5

These variables may not be the most important ones for a business person to examine when deciding whether or not to undertake foreign investment, but I see them as possibly the most salient in the media, and, therefore, to the average worker. First of all, most media organizations assign one (or more) of their best reporters to cover political leaders (e.g. presidents, foreign ministers, cabinet members), which means that their statements and

${ }^{3}$ There could also be many individual variables as well, such as military service, family background, education, and so forth, but these do not explain widespread tendencies.

${ }^{4}$ This is not to say that an authoritarian government would allow coverage of an embarassing worker uprising, but given enough media coverage elsewhere (and foreign media coverage was widespread by the 1970s), there is a great likelihood that other workers within that country would find out about the uprising.

${ }^{5}$ Wage rates may be another important factor, but unless workers are aware that they make more or less than others in comparable situations this kind of information would be of little help. 
actions are news. When such leaders speak on the subject of foreign aid and/or investment, not only does the coverage become more widespread, but so does the analyses of such news. This is due to the fact that national leaders are usually seen by a majority of the citizens as embodying all that the nation stands for, so their dealings with other nations are closely watched to make sure they fit in with the citizens' ideas of what they should be doing. In other words, if a majority of a nation's citizens feel that another nation should be dealt with harshly, but their national leader(s) treats this nation with compassion, this leader will probably be seen as weak or selling out his/her homeland. If this leader continues to treat the other nation with compassion and can convince his/her constituency that there are good reasons for such treatment, it may be that the citizens will change their point of view. If not, this leader may find him-/herself without a constituency. Because of the gravity of the situation in national relations, and the amount of media coverage such stories receive, I think that by studying the national leaders' attitudes toward foreign aid and/or investment $I$ can ascertain the general feeling on this subject within a nation. My first supporting hypothesis, then, is:

- If national leaders voice positive views towards foreign investment and/or intervention, then foreignowned MNC workers will have positive attitudes toward foreign-owned MNCs. 
As with national leaders, military activities are heavily covered by the media and reflect national attitudes (though not necessarily universal, a majority of a nation's citizenry will usually back their military). For example, in the U.S. during the Persian Gulf War, the outpouring of support for then President George Bush's actions against Iraq could be seen in the popularity polls that gave Bush his highest rating during his Presidential term. Though pacifists have been opposed to every major war in the Twentieth Century, including the Persian Gulf War, they are usually a small minority once military action has been taken. For this reason, if military action is taking place (or has recently) within the nations under study I can expect strong feelings of nationalism, and a negative view towards foreign aid and investment (both incoming and outgoing). This strong nationalism could possibly be neutralized by national leaders saying that the military activity is a necessary gesture of some kind (e.g. the restoration of democracy) and should not be seen as a 'national' statement. In such a case, citizens may view the majority of citizens of the other nation as unfortunate recipients of bad luck (or bad leaders) and should not be seen as enemies per se. Inward military activity would, in almost every case, generate extreme nationalistic 
attitudes. $^{6}$ In relation to my main hypothesis, my second supporting hypothesis is:

If a nation is experiencing military intervention of some kind (inward or outward), then foreign-owned MNC workers will show negative attitudes toward foreign-owned MNCs. 7

Strikes and worker unrest do not usually receive the type and amount of coverage given to national leaders and military operations, but the word "strike" (when used in conjunction with work and workers) carries a highly emotional charge. Strikes, no matter what the issue or players involved, are often thought of as pitting exploited workers against exploiting owner(s). It can be expected that if a high number of strikes take place within the countries (and especially in foreign-owned MNCs) that the MNC workers' attitudes would be anti-MNC (for that matter, anti-business), even if they are not involved within a strike. An interesting aspect of strikes within MNC work forces is whether workers employed by the same company (or

6 The bombing of London and Germany during WWII are prime examples of such military tactics that brought about extreme nationalistic views among the victims of the attacks (Seabury and Codevilla, 1989). Abbott (1988) notes that the same thing happened in Haiti during the U.S. occupation (1915-1933).

${ }^{7}$ This second supplemental hypothesis cannot be worded in the affirmative since an absence of military intervention would not necessarily bring about positive attitudes towards MNCs. The nationality of the other country would matter very little in this situation, as relations with this other country are based mainly on hostilities. 
same industry) in different countries would be likely to sympathize with each other during strikes. This was not the case in Dutch-based industries operating in India (Banaji and Hensman, 1990), or in the 1994 longshoremen strike in Canada. In the former, the workers in the different countries did not communicate during times of strikes (though the authors felt this would have improved the working environment for both parties), and in the latter, goods being shipped to Canadian ports were diverted to U.S. ports and shipped to Canada on overland routes. If this is the general tendency in such cases, it points out that workers are not seeing themselves on an international scale. 8 This leads me to my third supporting hypothesis: - If there is a small number ${ }^{9}$ of strikes within a nation, then foreign-owned MNC workers will have positive attitudes toward foreign-owned MNCs. The causal relationship stated in this hypothesis could run in either direction -- positive attitudes could lead to fewer strikes. Though this may be true, I think that if an industry or country is plagued by strikes, even

${ }^{8}$ It is interesting to note that MNC owners (or CEOs, or whoever is in charge) frequently transfer work to other operations in other countries during strikes (Kujawa, 1979). Whether or not this practice is the cause for the workers' willingness to do the work of other striking workers is worth investigating.

${ }^{9}$ An actual number is hard to pinpoint, and so the ambiguous term 'small number'. Though this could be just about any number, I will consider a nation to have experienced a small number of strikes if less than 200 were reported within a year. 
if foreign-owned MNCs are not directly involved, all workers could be anxious. This anxiety could be exacerbated within the foreign-owned MNC by knowing that labor negotiations are (possibly) carried out in another country.

Gross National Product (GNP) is not something that workers constantly see or hear within the media, but, because it is a leading economic indicator used by national leaders to gauge the economic strength of a country, it is mentioned often or used as a basis for a speech and/or political campaign. For this reason, I will make this part of my national equation. My fourth supporting hypothesis is as follows:

- If GNP is rising, then foreign-owned MNC workers

will show positive attitudes toward foreign-owned MNCs .

I separated GNP and GNP per capita because while GNP may be increasing arithmetically, the population of a nation may be increasing geometrically, and, therefore, the GNP per capita would be shrinking. ${ }^{10}$ If this is true, or for some other reason GNP per capita is falling or rising slower than GNP, then foreign-owned MNC workers will espouse negative attitudes toward foreign-owned MNCs. To rephrase this as my fifth supporting hypothesis:

${ }^{10}$ In the data analysis and testing of hypotheses, GNP and GNP per capita may be treated jointly, though they will have different values. 
If GNP per capita is rising at least as fast as GNP, then foreign-owned MNCS workers will have positive attitudes toward foreign-owned MNCs. Employment is one of the major concerns when talking about MNCs (Nicolaides, 1991), and therefore would gain much media exposure. ${ }^{11}$ Though the effect of MNCs on employment is still hotly contested (as shown in Chapter II above), it would seem that if a nation's unemployment rate were high, any firm (including MNCs) offering jobs would be considered to be doing a good service for the country and its workers. My sixth supporting hypothesis is stated as follows :

If unemployment within a nation is high, 12 foreignowned MNC workers would have positive attitudes toward foreign-owned MNCs. 13

Each of the above independent variables will be considered sufficient to cause positive or negative

${ }^{11}$ Unemployment rates or trends do not have to involve MNCs to get media coverage. As with GNP, unemployment rates are used as a major economic indicator (at all levels of an economy). This tends to exacerbate employment effects of MNCs.

12 once again, what is considered high unmemployment? I will choose six percent, since this is the high end of what economists within the U.S. say is the average rate of unemployment. Though I am not studying the U.S., I am using U.S. concepts when reporting unemployment rates.

${ }^{13}$ As with the second hypothesis, low unemployment does not necessarily mean negative attitudes. If a country is experiencing low unemployment, then more weight should be given to another variable. 
attitudes separately, 14 but not necessary. Unfortunately, it is not easy to treat each one separately, as they are interwoven (see Figure 1, though even this is misleading).

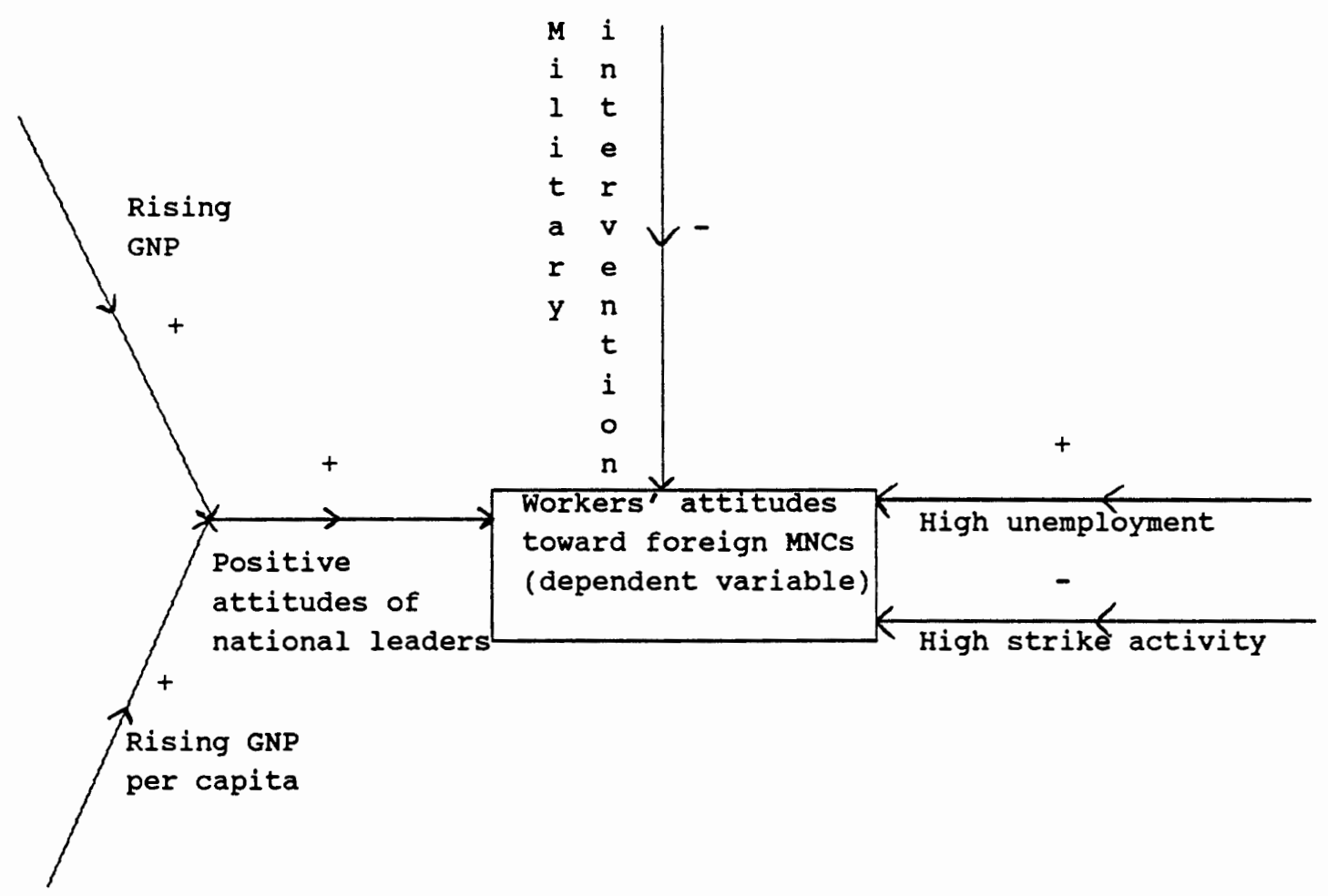

Figure 1. Model of hypothesized interactions of independent variables on dependent variable.

Elections can be won or lost over employment issues, which in turn may be tied to military activities and/or GNP figures. High unemployment may cause those still working to strike for guaranteed employment rights. I will present each independent variable separately when possible, but the

${ }^{14}$ Except the absense of military action, which is hypothesized to have no effect on the workers. 
nature of these variables does not always give me that opportunity. This should not be regarded as negatively affecting the study, as separating interdependent variables may have the affect of emphasizing or de-emphasizing them by taking them out of context, which would render them ineffective (atomistic fallacy), though the supporting hypotheses will be presented both separately and in combination.

Finally, a time frame must be set. Attitudes do not form in a vacuum -- historical events play a part, nor are they static -- the social identity paradigm allows for shifts in attitudes. For this reason, I will not trace the leaders, military activities, or strike histories of each nation back to the nations' inceptions. Each of these will be traced back two years before each study and the year in which the study took place, while GNP, GNP per capita, and unemployment rates will be traced back four years plus the year of the study. Though attitudes are formed over a lifetime, these time frames allow for some lag time impacts on attitudes -- an important feature in social identity theory, as well as immediacy effects. I turn now to the actual data analysis and testing of the supporting hypotheses. 
CHAPTER V

DATA ANALYSIS AND POSSIBLE DISCREPANCIES

I will try to reconstruct each nation separately by first looking at the independent variables that are treated in a qualitative manner. Because I think it is important to closely examine each country, some of the narrative may seem redundant. Hopefully this will not be the case throughout, but it is imperative that the reader be fully aware of cultural, political, and societal events that were taking place during the times when the questionnaires were administered. Events that may now seem trivial may have had major impacts on the respondents. When the independent variables are treated in a quantitative manner (such as GNP figures), I will present them separately (after the former) in tabular form. ${ }^{1}$ This will be followed by how my supporting hypotheses would predict the workers' attitudes toward foreign-owned MNCs, the results of the studies involving the MNC workers, and whether my supporting hypotheses predicted the actual outcomes.

${ }^{1}$ All the information given for each country has been taken from The New York Times Index, unless otherwise specified. 
Also, though I have chosen to study the two years prior to and the year the questionnaires were administered for each country (three years total), ${ }^{2}$ it is imperative that I spend a short amount of time on some general history of each country that may have played a part in the workers' attitudes. Any sociological study, longitudinal or otherwise, is lacking due to historical shortfalls -- this one included. The brief general histories are presented here to try to alleviate some of this deficiency.

\section{CANADA}

\section{General History}

Foreign direct investment to Canada (especially from the U.S.) has been strong since the mid 1800s. Serving a small market in a large geographical area did not suit Canada's late starting industrial firms, though U.S. factories had by this time achieved economies of scale that made it possible for them to service Canadian markets. In 1872, the Canadian government helped this process with passage of the Patent Act, which made companies who received patents in Canada use that patent within two years after issue. Since U.S. companies were so far ahead of Canadian firms in research and development, they took advantage of this new law. This continued well into the Twentieth Century -- Canadians received only five percent

${ }^{2}$ A total of five years for GNP, GNP per capita, and unemployment rates. 
of patents issued between 1968 and 1969, while the U.S. received sixty-seven percent and other countries twentyeight percent (Niosi, 1985).

Another act passed by the Canadian government that encouraged foreign direct investment was the Tariff Act of 1879. The resulting tariff measures forced many U.S. companies to bypass the tariffs by setting up MNCs. This was to shift later, but the immediate result was the overwhelming presence of foreign firms (mainly U.S.) in many sectors of the Canadian economy (Niosi, 1985).3

In 1965, the U.S. and Canada signed a trade agreement covering automotive manufacturing concerns in both countries. 4 The canadian automotive industry had been inefficient after World War II, and looked to its southern neighbor to strengthen this sector. The U.S. had become the number one car manufacturer in the world after WWII, and its invitation into Canada was met with open arms by many Canadians. Between the signing of the agreement in 1965 and 1973, Canada's automotive production increased tremendously. This increase was accompanied by sizable increases in employment within the sector. Canadian autoworkers gained wage parity with U.S. autoworkers during this time as well. These two factors (production and

${ }^{3}$ Foreign capital investments in Canada for 1969-1971, the period under study, was as follows (millions U.S.\$): $1969-41,602 ; 1970--44,037$; and, $1971--46,250$.

${ }^{4}$ Ford Canada, which employed the workers questioned, was established in 1904 (Maxcy, 1981). 
employment increases) gave most Canadians reason to feel comfortable with the agreement, but there were those that felt the U.S. had overstepped its boundaries and even more workers could be employed if Canadians were doing the hiring. Plus, governmental inducements and incentives for U.S. companies caused small schisms to appear between the signatories of the agreement (Maxcy, 1980). Since the workers questioned were employed by Ford Canada, these matters may have influenced perceptions of their employer.

\section{Politics}

Much resentment towards the U.S. (and U.S. investments) could be found in Canada between 1969 and 1971, though this animosity was not aimed at all foreign countries. Early in 1969, Minister Edgar J. Benson said that domestic fears of Canadian economic subordination to the U.S. may have some basis, and Prime Minister Pierre Trudeau backed this with the notion that some sectors needed to be protected from foreign investments and started talks on a ban on foreign ownership. This came on the heels of a small economic boom in the Western Provinces that was spurred by Japanese investments. Some feared these investments, but Trudeau said such (Japanese) investments were inevitable. This apparent contradiction points out that Trudeau and his government may not have been so worried about foreign investment as long as it did not come from the U.S. 
After Canadian officials made it clear that they believed Canada had better long-run economic potential than the U.S., the Canadian Cabinet approved a bill in 1969 that would create the Canada Development Corporation. Though this organization was to oversee all foreign investments, it was clear that it was specifically directed towards U.S. investments. Since much of U.S. investments could be found in existing firms, Canadians were fearful of U.S. investors continuing this pattern and taking over what would, in all regards, be turnkey operations for U.S. firms. This would mean less capital going to sectors such as construction. The Canada Development Corporation was meant to mobilize Canadian funds to stave off such ventures. Some even felt it should be used to cleanse the country of all U.S. investments. Though the corporation would not materialize until 1971, a high level effort was begun to minimize U.S. investments.

Minimizing U.S. investments in Canada was not easy. Shortly after the bill was passed to establish the Canada Development Corporation, Trudeau was again facing public pressure to immediately halt continued U.S. investments. Some even called for nationalizing some sectors, though this was quickly turned down by the government. Not only did Trudeau and his government have to appease the public, but he was also getting bad news from the academic world. One study showed that Canadians had not thought deeply about U.S. economic control through U.S.-owned subsidiaries. Now Canadians were being told that effects 
of U.S. economic domination could possibly be worse than they had feared.

Whether to divert internal concerns over U.S. economic control, or possibly as a statement to the U.S. and concerned Canadian citizens that he, Trudeau, was in charge of Canada, he made it publicly known that talks were to begin with Communist China. The U.S. voiced its concern over this decision, resulting in a Washington D.C. visit by Trudeau to discuss Canadian and U.S. policies with President Richard Nixon. After the meeting, Trudeau announced that Canada would continue to have friendly ties with the U.S., but that Canada must pursue independent policies from that of its southern neighbor. Talks with China were immanent.

Trudeau's critics called the U.S. visit inconclusive, but shortly thereafter Trudeau began talks with Peking, saying Canada was moving away from being a U.S.- and European-oriented nation. Benson reiterated this sentiment by saying that Canada was not a political satellite of any other country, and need not worry about the U.S.'s dislike of talks with Peking. Trudeau not only felt that Peking was important to Canada's future, but that Asia in general, as well as Latin America, were important. Trudeau pointed to the growing amount of trade between Canada and Japan as an example of other countries' importance.

Unfortunately for Canada, beginning diplomatic talks with Peking meant the possiblity of severing existing ties with Taiwan (Nationalist China). This is what happened, at 
least for a short time. Taiwan was not ready to trade with a country that seemed so intent on pursuing friendly ties with its nemesis and quickly severed ties with Canada. This meant that not all of Asia was ready to negotiate with Canada (or at least not all at the same time). Still, Canada continued talks with Peking throughout 1969, though little progress was made.

Not only did Canada begin diplomatic ties with Peking in 1969, it also openly courted the U.S.S.R. Soviet Foreign Minister Gromyko toured ottawa, much to the displeasure of U.S. officials. Again, observers felt this was aimed at distancing Canadian foreign relations policies from those of the U.S. Whether or not this was the goal of Trudeau's administration, it was obvious that the U.S. was not welcomed with open arms. This could be seen in the opposition mounted against Phillip Morris' offer to buy fifty percent of Canadian Breweries Ltd. common stock. The deal was defeated. Canadian officials were even quick to point out that they were increasing their foreign aid to poor countries while the U.S. lowered its foreign aid, though the U.S. was still higher in absolute figures. Canada's anti-U.S. measures (in the economic realm) continued in 1970. After U.S. officials noted that the U.S. and Canada needed to become a trading bloc (without jeopardizing Canada's sovereignty), and that MNCs were the best way to turn Canada's natural resources into capital, Canada officials refused to allow a U.S. company to buy controlling interest in Canada's largest uranium mine. 
This move was seen as an intensification of economic nationalism on the part of Trudeau. Shortly after this, the U.S. once again sent Canadians (officials and citizens alike) scrambling when the commerce Department forecast a massive rise in U.S. investments going north -- close to $\$ 2.7$ billion.

The economic nationalist's increasing cries for government intervention on behalf of a separate canadian economy -- two-thirds of manufacturing and mining industries in Canada were foreign owned in 1970 with the U.S. owning well over half of the latter and almost as much of the former -- seemed to be getting through to Canadian officials. Minister John James Greene said that the U.S. must prepare for a Canada that would have stringent control over all foreign investments, no matter what the industry. Some canadians began to be worried about domestic security firms and felt that foreign companies had no right to ownership of these firms. A proposed sale of Ryerson Press, Canada's oldest publishing house, to U.S.-owned McGraw Hill was adamantly opposed and eventually fell through. When a cry went out that U.S. interests were buying up recreational lands, economic nationalists were quick to play up the concern. Pravada, U.S.S.R.'s official government newpaper, added fuel to the economic nationalists' fires by reporting anxiety within the U.S.S.R. over U.S. business ties in Canada.

Government-level talks between Canada and the U.S. oscillated precipitously. In the midst of cries for 
economic nationalism and measures to curb U.S. investment, Canadian officials seemed torn between wanting less U.S. capital and needing more to keep the Canadian economy growing. Though many new policies were seen as restricting new U.S. investments, a government report on future foreign policy noted that the U.S. would remain Canada's closest friend and ally (this latter word may be key to why the report was written in such a way). The report, though, said the two countries must be distinct, and that ties with Europe, Asia, and Latin America must be nurtured. Canadians also showed dissatisfaction with President Nixon when he did not mention Canada in his state of the World Message, and were less than pleased with a visit from the U.S. Under Secretary. In Toronto, a firebomb was thrown through the U.S. consulate's window as some Canadians acted out their displeasure over U.S. presence. Still the two nations did come together to start a joint venture to curb drunk driving, although this may seem insignificant in light of the turbulence in economic matters.

Canada's other foreign policy decisions were aimed at continuing the increase of foreign aid and continuing to nurture ties with Communist China. After twenty months of diplomatic talks, Canada did recognize Peking. Many Canadians, both in Trudeau's and the opposition's party, saw this as a sign of gaining independence from the U.S. Shortly afterwards, Canada sent an envoy to China, though the move was not reciprocated. Canada's ties with Taiwan took a complete turn during these relations. First, Taiwan 
reversed its decision to severe economic ties with Canada, saying the talks with Peking had no impact on their relations. But then, immediately after Peking was recognized, Taiwan did severe ties. Also, though Nixon was to travel to Peking shortly after Canada recognized Peking, the U.S. made it known that this new diplomatic relationship would not affect U.S. policies toward Communist China or Canada. Canada was actively seeking opportunities for overseas investments as well. The Canadian International Development Agency, which granted moneys for exploratory and feasibility studies for canadian firms looking to invest overseas, was established in 1970 (Niosi, 1985). The Development Corporation followed in 1971 .

After 1971, the Development Corporation became a permanent part of the Canadian landscape. 5 Its development was slow, however, because some canadian businessmen saw anti-U.S. economic policies as hurting Canada's economy, especially after the OECD stated that Canada would continue to be a hotbed for U.S. investments. This debate seemed to cloud the picture of economic independence. Trudeau's administration felt the need for U.S. investments to create new jobs -- unemployment was over six percent --, but knew there was widespread public support for Canadian

${ }^{5}$ The Development Corporation helped Canadian-based MNCs and other foreign direct investments by offering such services as foreign investment insurance (Niosi, 1985). 
independence that was supposedly imperiled by U.S. investments. It seemed like the latter had more weight. When a U.S. company sought to begin a paper/pulp mill in Northwest Saskatchewan (a region with high unemployment) it was seen as a setback for Canadian economic independence. A Premier election in that Province was won by the candidate that was most opposed to U.S. investment. Other government shakeups were the result of a perceived need to curb foreign (U.S.) investments. Also, Canadians found little comfort in Nixon's reassurances that the U.S. had no intentions of making Canada a U.S. colony -- they felt threatened whenever the U.S. mentioned some kind of economic bloc pact. When U.S. companies tried to freeze wages in Canadian subsidiaries, angry Canadian officials said U.S. companies had no right to force policies on its subsidiaries. In ottawa, a move was made to nationalize all resource industries (though the government did reject the proposals). In ontario, Premier William G. Davis' government was said to be nationalistic and, indeed, did begin giving tax breaks to Canadian firms. These fears soon spread to concerns over U.S. dominance in Canadian education and communications. ${ }^{6}$ To a certain extent, even Canadians working in the U.S. were viewed by their fellow citizens as turncoats. A surcharge on Canadian firms'

${ }^{6}$ See McPhail (1987) for an explanation of Canada's media being an example of developing journalism due to the presence of the U.S. (esp. pg. 24-32). 
exports to the U.S. was considered a deplorable tactic for decreasing pressure on U.S. companies who wanted to invest in Canada. This had the obvious effect of more anti-U.S. sentiments. There was one area of agreement between some citizens of Canada and the U.S.: Disapproval of Vietnam. New Democratic Party members in ottawa put on a demonstration to show their support for U.S. antiwar protesters. Still, this show of solidarity seemed to do little for the overall public sentiment in regard to the U.S.

Even with the continued feelings of anxiety toward U.S. investments, some Canadian officials began fearing Canada's anti-U.S. policies. At least half of the Premiers noted that Canada could not become self-sufficient and needed U.S. financial support. The Niagara Institute for International studies was also formed to develop a better understanding of U.S.-Canada relations in hope of quelling some of the fears. Trudeau even called on Nixon to help Canada get out from under U.S. influence, though both said they would continue to work on close ties between the two countries.

The two sides to this issue seemed to make Trudeau schizophrenic when it came to U.S. relations, though his Liberal Party was seen as pushing for more economic nationalism. Some saw Trudeau as more nationalistic than his immediate predecessor -- L.B. Pearson. In regards to the Development Corporation, Trudeau felt it was imperative that this organization get up and running to curb U.S. 
investments. He then turned around and said the two countries must work for closer ties. When Nixon made it public that he was going to visit Peking, Trudeau said that he was always one step ahead of Nixon; this was after he had asked Nixon to help Canada get out from under U.S. influence. The two leaders exchanged visits during the year, and the governments signed an extradition treaty on assailants of diplomats. When it came to U.S. relations (especially in the area of investments), Canadians were beginning to get a mixed signal from their Prime Minister. other foreign policy was more clear. Though early in the year China said it was not ready to buy American imports, the two countries did exchange ambassadors before year's end. Relations with the U.S.S.R. also continued, as Trudeau made a visit to the U.S.S.R., and entertained Soviet Premier Aleksei Nikolayevich, who was thought to be hoping to show that Canada could have other friends in the global community (besides the U.S.). Though Nikolayevich was met with protesters in parts of Canada (over the U.S.S.R.'s human rights record), Canada and the U.S.S.R. signed an amity pact, and agreed to industrial cooperation. These moves were seen as both positive and detrimental for Canada-U.S. relations. Some felt that it was yet another sign of Canadian independence, while others feared it would split the two countries with Trudeau spending too much time courting the U.S.S.R. Trudeau disagreed with these latter sentiments. Plus, after a European-owned bank opened its 
doors for business, Canadians saw signs of extended European ties, easing fears of a total turn to the U.S.S.R.

\section{Military Activities}

Canada did not engage in any type of warfare during the three years under study, though she did continue her membership in NATO and participated in joint military activities with the U.S. This included a Distant Early Warning Line, an affirmation that the defense of North America was the second highest mission of Canada's Armed Forces, and drills involving joint bomber runs over Canadian air space. The use of Canadian air space, though, was also an area of contention. The U.S. wanted to have access to Canadian air space for its anti-ballistic missiles, but was turned down and told by Defense Minister Donald S. MacDonald that Canada would link with the U.S. in all military concerns, except in an antiballistic missile system. 7

The U.S. was eager to use Canada's North Bay military base as an alternate air defense base, but this request was denied as well. The U.S. also berated Canada for not carrying more of the financial load of protecting North America after it cut military spending in 1969. Canada, partly in response to the U.S. asking it to share more the burden of North American military defense, increased its

${ }^{7}$ Just ten years earlier (1961), sixty-one percent of Canadians believed Canada's military should be equipped with nuclear weapons (Gallup, 1972). 
military budget in 1971 by $\$ 18$ million, though the U.S. complained that this was still not enough. Canadian officials said there were better ways to spend money.

\section{Labor -- Strikes and Unemployment}

Rising inflation between 1969 and 1971 had many Canadian workers worried about their futures. Inflation was not the only factor blamed on rising unemployment -U.S. investment was carrying part of the blame as well, with U.S.-owned companies being accused of downsizing and as fronts for U.S. exports to Canada.

Trudeau's foreign investment policies have already been reported, so I now turn to his anti-inflationary policies, which directly affected workers. Trudeau decided the best way to defeat inflation was to enact a voluntary wage freeze, which labor leaders and workers contested. These policies were expected to have a large impact on the 1972 elections, while inflation and unemployment continued to rise (though unemployment did level off somewhat in 1971).

The worries over inflation and unemployment also caused worker unrest during the three years under investigation. Over 500 strikes were reported each year (see TABLE VI, page 59), including a Ford Canada walkout in 1969 (to respect other United Auto Worker picket lines), and another strike in 1971 over wages and other benefits. 8

${ }^{8}$ Unfortunately, Marton did not include this as part of her study of Ford Canada workers. This is the kind of 
Air Canada workers -- who are government employees -- also struck in 1969. In addition, Quebec was a breeding ground for worker unrest, mainly due to the separatist activies in that Province. I now turn to these activities.

\section{Quebec}

Though Quebec itself played no larger role in foreign relations/investment than did other Canadian Provinces, the separatist activities there were a major part of the Canadian social and political landscape during the years under consideration. Strikes and political activies in 1969 were the harbingers of more extreme activities in 1970. These activities may have been exacerbated when France's Secretary of state for Foreign Affairs turned down an invitation to visit ottawa after a trip to Quebec.

By 1970, some of the more extreme separatists had resorted to the kidnapping and murdering of government officials. Trudeau, in retaliation to these offenses, evoked emergency wartime powers. U.S. and French officials praised him for his actions, though some Canadians criticized him for using too much force too quickly.

Extremist activities in Quebec had died down by 1971 , though rising unemployment was the cause for some worker unrest in the region. Many Canadians were still uncertain of Quebec's future. It seemed that the Canadian and French

oversight that needs to be corrected in social science studies, as people's attitudes are treated as if they were formed in a vacuum instead of a society. 
governments had come closer to seeing eye-to-eye on the importance of maintaining a united Canada. By mid-1971, Trudeau and the rest of Canada seemed to have brought Quebec back into Canadian Iine.

\section{Quantitative Data}

TABLES IV, V, and VI contain the quantitative data for Canada.

TABLE IV

GNP AND GNP PER CAPITA, CANADA 1967-19719

Year GNP(millions U.S.\$) GNP per capita (U.S.\$)

1967

1968

1969

1970

1971

Year

1967

1968

1969

1970

1971
$48,649.5$

$51,099 \cdot 110$

$79,130.0$

$89,320.0$
2380

2460

2650

3700

4140

\section{TABLE V}

UNEMPLOYMENT RATES, CANADA 1967-197111

Unemployment Rate

3.8

4.5

4.4

5.7

6.2

${ }^{9}$ Source: World Bank Atlas, 1969-1973. GNP and GNP per capita figues for all countries are not adjusted for inflation, but are in absolute (current) figures.

${ }^{10}$ The GNP for 1967-1969 were estimated by using population and GNP per capita.

${ }^{11}$ Source, Kearl (1993) 
TABLE VI

NUMBER OF STRIKES AND WORKERS INVOLVED, CANADA 1969-197112 Year \# of strikes \# of workers involved

1969

$1970 \quad 503$

1971

547

Hypotheses, Predictions, and Data for Canadian Workers

I turn now to the supporting hypotheses that I stated would predict the outcome of workers' attitudes toward foreign-owned MNCs.

- The first would be that if national leaders expressed positive attitudes toward foreign investment and/or intervention, then workers would also show positive attitudes. The case here is not absolutely clear, since Canada began diplomatic talks with Peking during the time under study, courted the U.S.S.R., and stated that more needed to be done in relations with other regions of the world, such as Latin America and other Asian countries. What is clear is the anti-U.S. views of the national leaders. Since a large majority of Canada's foreign investment was from the U.S., it is safe to say that a majority of Canada's foreign investment was viewed as negative by national leaders, and, therefore, workers would be predicted to have negative attitudes toward foreignowned MNCs.

${ }^{12}$ Source, Leacy (1983). 
- The second hypothesis was that any military intervention (inward or outward) would lead workers to espouse negative attitudes. Since Canada's military was, for the most part, inactive, except in joint practices with the U.S. and in quelling some of the unrest in Quebec, workers would not be affected by military activity in regards to national or international feelings.

- The third supporting hypothesis stated that if strike (or worker unrest) activities were high, then workers would have negative attitudes toward foreign-owned MNCs. Canadian strike activity was high each year of the study, with over 500 strikes taking place each year. Ford Canada workers were involved in strikes in two of the years (1969 and 1971). This would give reason to believe, according to this hypothesis, that the workers questioned would have negative attitudes toward foreign-owned MNCs.

- My fourth and fifth supporting hypotheses concerned GNP and GNP per capita. The former stated that if GNP was rising, then workers would have positive attitudes toward foreign-owned MNCs. The latter stated that if GNP per capita were shrinking or not rising as fast as GNP, then workers would have negative attitudes. GNP and GNP per capita did rise each year, though GNP rose faster than GNP per capita. Thus, though GNP was growing (creating a stronger economy) workers were not enjoying the same percentage of growth in their incomes. Therefore, workers would be envisioned to have negative attitudes, though this would be tempered by the rise in both economic indicators. 
The sixth hypothesis stated that if the country in question experienced high unemployment ( $\geq 6 \%)$, then workers would have positive attitudes toward foreign-owned MNCs. Since Canada experienced high unemployment only one of the years (1971), workers would not be predicted to have strong positive attitudes toward foreign-owned MNCs, though the last year of high unemployment may have moved some workers to be grateful for the work.

A combination of the six supporting hypotheses predicts negative attitudes toward foreign-owned MNCs. None of the conditions documented gave workers reason to have positive attitudes, though circumstances relevant to the second and sixth hypothesis were neutral. From a social identity theory perspective, Canadian workers would view MNCs as negative if they are non-economic persons. This is the result that was obtained from the actual questionnaires (which was administered by Marton at the Ford plant. 13 TABLE VII (page 64) shows the percentage of responses to a question concerning the overall attitudes of the workers. 14

13 The number of workers who participated in the Canadian study was 100 .

${ }^{14}$ The actual question was: "What is the overall effect on Canada of the activities of foreign companies in Canada?" (Marton, 1982, pg. 85). Responses were operationalized on a seven-point Likert-type scale, with possible responses ranging from bad (1) to good (7). 
Fifty-six percent of the workers had negative attitudes toward MNCs, while only thirty-one percent had positive attitudes. Thirteen percent were noncommittal.

\section{TABLE VII}

WORKERS' OVERALL EVALUATION OF MNCS IN CANADA 15

\section{Rating}

1 (bad)

2

3

4 (neutral)

5

6

7 (good)
$\%$ of respondents

To analyze the variation in overall attitudes among the workers, it was regressed on nine evaluative beliefs: MNCs' 1) influence on Canadians way of $\left.\operatorname{life}\left(\mathrm{x}_{1}\right), 2\right)$ working conditions $\left.\left(x_{2}\right), 3\right)$ wages $\left.\left(x_{3}\right), 4\right)$ recognition of unions $\left.\left(x_{4}\right), 5\right)$ effect on Canada's economy $\left.\left(x_{5}\right), 6\right)$ future effects $\left.\left(x_{6}\right), 7\right)$ involvement in national affairs $\left.\left(x_{7}\right), 8\right)$ acting contrary to Canadian interests $\left(x_{8}\right)$, and 9$)$ moneys other than wages $\left(x_{9}\right) .16$

By forming a multiple regression analysis of all nine beliefs, the following unstandardized regression equation was produced: $0=-.85+.28 x_{1}+.25 x_{2}+.06 x_{3}+.17 x_{4}+$ $.35 x_{5}+.18 x_{6}+.20 x_{7}+.05 x_{8}+.42 x_{9}$

${ }^{15}$ Source for all the tables for the Canadian workers are from Marton, 1982.

${ }^{16}$ Respondents answered each question on a seven-point likert scale (as in the "overall responses"). 
where 0 is the overall attitude of the workers.

This equation produced a multiple correlation coefficient with overall attitudes toward foreign investment of .85 , so $R^{2}=.7225$. This equation, though, had intercorrelated variables, and after computing $t$-values for the betas, Marton found that only three were significant at the .05 level $-\mathrm{x}_{1}, \mathrm{x}_{5}$, and $\mathrm{x}_{9}$, with $\mathrm{x}_{1}$ explaining the most variance $\left(R^{2}\right.$ for this variable was .60 in a stepwise regression analysis). 17

Since $x_{1}$ - MNC influence on way of life -- explained sixty percent of the variation between respondents, it would seem that a powerful case could be made that there is a strong relationship between nationalism and attitudes toward foreign-owned MNCs. But are Ford Canada workers more nationalistic than their fellow Canadians? In a survey conducted the same year as the Ford Canadian study, 5000 Canadians were asked if they harbored negative attitudes toward U.S. investments. Only thirty-nine percent (1970 respondents) were outright negative. ${ }^{18}$ This is a large difference, and suggests a exacerbation effect

17 Standardizing the betas may have given us even more insight into the effects of each of the beliefs, but this was not included in Marton's study (nor was the information needed to perform the calculations, so the results could not be checked). The t-values, though, do give us an estimate of what linear relations may be found in the population (assuming this was all Canadian workers in "blue-collar" positions within foreign-owned MNCs).

${ }^{18}$ If a chi-square test of independence were conducted using the two groups, the significance level would be above ninety-nine percent. 
of working within a foreign-owned MNC. (This is not to say that causation has been found in either direction, but to point out the strong relationship between nationalism and negative attitudes toward foreign-owned MNCs. ${ }^{19}$ ) I turn now to Brazil to find out if workers employed within foreign-owned MNCs there had the same attitudes toward their employers as did the Canadian workers.

\section{BRAZIL}

\section{General History}

Brazil proclaimed its independence from Portugal in 1822 , and has struggled to shake the effects of its colonial past ever since. This has not been easy. Though Brazil boasts the largest land area and population of any country in South America, which means both large raw material deposits and an ample supply of labor power, it has not been able to develop without the help of foreign investment. This has usually come in the form of

${ }^{19}$ A Iinear relation between nationalism and employment within MNCs (or any other variable) becomes even more problematic when nationalism is studied across age and temporal boundaries. In a survey involving Canadian high school students conducted in 1968, over 60 percent of the respondents said that U.S. interests hold too much control over Canadian resources (Forbes, 1985), but another study done around 1964 found a nearly unanimous acceptance of U.S. investments among English-speaking Canadian college students (Clark, 1965). Social identification theory approaches these different intensities of nationalism by searching for positive self identification factors, which makes linear relations less problematic. (In other words, the intensity of nationalism starts within the person or group based on societal factors; see Chapter VI below for a further explanation.) 
investments by MNCs (mostly from the U.S., though in no way has it been confined only to the U.S.) (Horowitz, 1964).

In 1960, Brazil became a member of the Latin American Free Trade Association (LAFTA). As with most integrated trade pacts, LAFTA was formed with a desire to strengthen the individual nations' economic situations. Shortly after LAFTA was formed, Brazil emerged as the economic leader, which led to small rivalries with some of the other nations involved, such as Argentina and Chile. This continued into the '70s as will be seen shortly (Jones, 1991). In spite of these small rivalries, LAFTA stayed intact.

Though LAFTA had some success in helping Brazil's economy grow, it took a military coup in 1964 to make it really expand. The coup was brought about by high inflation, which in turn caused worker strikes and riots. This unstable situation may have caused U.S. investors in Brazil to help finance the coup, as the U.S. Navy dispatched ships to back the coup. The ships never made it that far, as the coup was successfully completed within a couple of days (Shoumatoff, 1980).

Before and after the coup, the U.S. had been the largest foreign investor in Brazil (and this has continued). According to Horowitz (1964), this made the U.S. a scapegoat for Brazilian nationalists. Even though U.S. companies were undoubtedly the best taxpayers, as well as the best wage payers in Brazil, this had not made them any more welcome. As a matter of fact, an ex-President of Brazil, Janio Quardos, wrote that Brazil must get out from 
under U.S. control (Horowitz, 1964). All of this was written before 1964. The Brazilian workers involved in the study were questioned in 1974. How many, if any, changes occurred during those ten years?

Before I outline the events in Brazil from 1972 through 1974, it should be noted that many outside of Brazil felt that it was the perfect country for foreign direct investment. LaPalombara and Blank (1984) even named a model for foreign investment the "Brazilian model," commenting that other countries could learn from what Brazil had done. They pointed out that a major reason for this success was the military regime and the amount of governmental support for already existing MNCs. Others hailed Brazil's economic growth in the early and mid 1970's as an economic miracle, as its GNP rapidly increased throughout these years (Brockway, 1993, Larrain, 1989). It was only after the mid 70's that social scientists recognized that, as with most developing countries, this success was achieved at the expense of the bottom half of the nation's population (actually more than half, as more Brazilians were below the average income than above). The gap between rich and poor was widening at the same rate the GNP was rising (Maxcy, 1981).

\section{Politics}

Nineteen-hundred-seventy-two marked the 150th anniversary of Brazilian independence. Many celebrations were planned and carried out with the hope of stirring 
public pride in Brazil. While this may be interpreted as a showing of nationalistic pride, Brazil's economic growth at this time was, in fact, fueled by foreign investment.

Brazil entered 1972 coming off the best year in its economic history with an increase in GNP of eleven percent. This was helped by several billion dollars of both domestic and foreign investment. To continue this growth, Brazilian officials decided to continue to invite foreign companies to begin operations in Brazil. This was not only for continued economic strength, but also as a source of jobs. Even though pollution caused by such companies (many were natural resource ventures such as paper/pulp mills and mining extractors) was the cause for some concern, highranking Brazilian officials felt that this was not a worry at the time, and when it did become a problem the rich industrial countries would clean it up -- since they were the ones that caused it (through their subsidiaries). Though the U.S. was the major foreign investor in Brazil in 1972,20 and even sent a group of officials to study Brazil's economic growth, other countries saw this South American country as a target for investments as well. Japan set up a paper/pulp mill in Brazil during 1972, and sent a national mission there to investigate investment opportunities and economic cooperation between the two

${ }^{20}$ U.S. companies saw Brazil as a good place to set up operations as they fought high wages and stringent pollution controls at home. 
countries. Japan had close to 700,000 expatriates in Brazil in 1972. In all, it was estimated that over one billion dollars of new foreign investment and bank loans entered Brazil in 1972.21

Brazil was also looking outward at this time. The Brazilian government put pressure on foreign-owned MNCs to look for new markets for export goods. The Brazilian leaders said this was the price to pay for continued incentives given to MNCs. Africa was even courted as a possible partner for economic cooperation, as were Latin America countries. Brazilian President Emilio Garrastazu Medici signed a law creating new Brazilian trading companies based on the Japanese model. The companies were to be Brazilian owned, though foreign partners were free to join as long as majority ownership was Brazilian.

Many within and outside of Brazil saw these proceedings as Brazil's move to become the leader of the Third World. There were critics, however. The Roman Catholic Church and the Government feuded over the treatment of native populations, as The Church accused the government of displacing these people by allowing MNCs to expand into Brazil's rain forests. Others saw Brazil's

${ }^{21}$ Both the U.S. and Japan sent loans to Brazil in 1972. The U.S. Export-Import Bank announced two one million dollar loans so Brazilians could purchase U.S. goods and services in heavy machinery, while Japan issued over \$32 million doliars worth of bonds on behalf of the Brazilian government during the year (it should be noted that this did come after suspension of 3 Brazilian bonds on the New York Stock Exchange). 
economic growth as a way to continue low wages and military oppression. When Amnesty International made claims of torture against the Brazilian government, the U.S. threatened to end military aid. ${ }^{22}$ Further, many in the Latin American community pushed for Brazil to end its Cuban Boycott and increase trade with the U.S.S.R. This latter development may have been hindered when possible U.S.S.R. informants were arrested for subversion against the Brazilian government. Finally, in an act that was seen as a move to strain British-Brazilian ties, a British sailor on shore leave in Sao Paulo was attacked and killed by rebel guerrillas. It did little good.

Brazilian officials continued to encourage FDI in 1973, as Brazil continued its quest to become a developed nation. Though many in Brazil hoped to do this with less dependence on FDI (true economic progress was seen to be Iinked to national pride), others in Brazil looked to Japan, Europe, and the U.S. for continued support. Japan was held as a model of economic achievement given its fall and rise after WWII. MNCs from other countries seemed to be more than happy to continue to take advantage of Brazil's raw materials and large (cheap) labor force. Foreign relations with the U.S. were apparently not hindered by the threat of withdraw of military aid made in

22 This may have been of little concern at the time, as $\$ 59$ million worth of air traffic control and air defense radar systems had been purchased from the French in 1972 . 
1972. As a matter of fact, the U.S. sent jet fighters to Brazil to help in military matters. U.S. President Richard Nixon noted that Brazil was the natural leader for Latin America and began building new ties with Brazil. There was, however, one small problem with relations between the two countries that occurred over the sale of real estate. A deal that was to involve the U.S. selling an old embassy building to West Germany was vetoed by the Brazilian government. The sale was seen as a tax evasion measure on the part of the U.S. participants. This may have caused a small rift in U.S.-Brazilian ties, but one would have to wonder how much it would have affected the general public, especially since nothing more came of it (no threats to invade Brazil or pull all aid from that country).

While U.S. relations continued to be mostly friendly through 1973 and Brazil continued to look to other developed countries as a way to continue its economic progress, relations with other Latin American countries were deteriorating. After Nixon's statement regarding Brazil's leadership potentials, relations with Argentina began to cool. other Latin American countries saw Brazil as becoming imperialistic, especially towards its closest neighbors. Brazilian officials shot back with statements that it was being used as a scapegoat for the problems experienced in these other Latin American countries.

Relations with some other countries were also becoming problematic. Japan became the target for some government concern. Fears of pollution and natural resource depletion 
caused the Brazilian government to insist that a new Japanese factory use the most advanced pollution control devices in the construction of the plant. Though this did not move the Japanese to withdraw from Brazil, it can be seen as a move towards more control over FDI. It was also feared that boycotts by Arabs, or any cutbacks in energy supplies from them, would trigger a halt to Brazil's economic growth. The National Monetary Council of Brazil ordered a forty percent reduction in the foreign exchange reserves held in Brazilian banks (estimated to be at $\$ 6.4$ billion U.S. dollars). These funds were seen as having adverse affects on inflation.

Though Brazil experienced the largest gain in GNP (eleven percent) of any major nation in 1973, it did begin to experience an economic slowdown toward the end of 1973 and the beginning of 1974 (a trend that was to continue). This slowdown was blamed mainly on a balance of payment problem stemming from dependence on imported oil. 23 Brazilian officials (led by newly selected President General Ernesto Geisel) began courting Arab investments, hoping to lower the balance of payment debt and ensure that no boycotts within this sector would happen. Arab bankers and industrialists took this opportunity to look seriously into investing in Brazil. Some inside and outside Brazil were beginning to question Geisel's open arms policy, much

${ }^{23}$ Approximately eighty percent of Brazil's oil was being imported at this time. 
of this criticism stemming from a growing concern over the environment.

Brazil's foreign relations under Geisel seemed to become somewhat more disorganized, though many still saw Brazil as having the potential of becoming a world power. U.S. relations continued to be strong for the most part, ${ }^{24}$ as First Lady Pat Nixon was a guest at Geisel's inauguration, and Brazil looked towards U.S. investments as a possible solution to its growing economic problems. There was some worry over trade barriers between the two countries, especially after Brazilian officials accused the U.S. of trying to place import duties on Brazilian shoes. Nixon sent a top advisor to Brazil to iron out the differences. Secretary of State Henry Kissinger seemed to have done little to promote relations. He was given a lukewarm warm welcome when he visited Brazil later in the year. (This was mainly due to Kissinger's public backing of the Netherlands' soccer team during a Netherlands-Brazil soccer contest the preceeding year.)

24 There were two isolated incidents involving U.S. citizens in Brazil that could have hindered ties. A U.S. journalist was arrested after interviewing outgoing Brazilian President Juan Domingo Peron. This arrest was based on charges of incriminated evidence of the ruling military party -- evidence that had reportedly been made up by the journalist. The second incident involved a U.S. businessman who was arrested and supposedly tortured over charges of stealing monies. Though U.S. Officials demanded humane treatment from Brazilian officials, the incidents seemed to have had little impact on ties between the countries. 
Brazil was still seen as an up and coming power in Latin America, especially by Argentina. Geisel and his officials continually denied these charges, saying Brazil was not out for power, but trying to develop economically. Nevertheless, Argentinean officials continued to be outspoken critics of Brazil. Paraguay and Bolivia were pursued in the hopes of establishing economic ties. Brazil and Bolivia even signed an economic cooperation pact, and Geisel used this as a start towards Latin American solidarity and integration. He was met with student protests in Bolivia shortly after the pact was signed. These students were concerned about Brazil's perceived power and militaristic government.

Brazil established ties with Communist China in 1974, though, as with Canada's ties with Communist China, this came at the cost of losing diplomatic ties with Taiwan. With ties to Peking, Brazil was hoping to buy Chinese coal, chemical products, and oil. Though it was not explicitly mentioned, it was a move to reduce her reliance on Middle East oil. Also, Brazil pursued possible joint ventures with the Chinese in steel production. In addition, other communist countries, such as the U.S.S.R., were approached, though no such breakthrough was made with Cuba. Arabs were looking into investments in Brazil as well, though progress here was tied to Brazilian officials' willingness to back the Arabs' conflict with Israel. In an international development, Brazil sent a contingent to fight for the right to continue population growth at the U.N. World 
Population Conference -- this was the opposite stance from most other Third world countries, a move that could be viewed as nationalistic.

\section{Military Activities}

Military operations during the period under study were mainly limited to fighting anti-government guerrillas. Very few military regimes in the Third world are safe from guerrilla actions aimed at overthrowing the current regime. Though this action was small in 1972, it was to pick up later.

Military activity involving Brazilian forces continued to be focused internally in 1973 and 1974. Though the Popular Revolutionary Vanguard (the largest Brazilian guerrilla organization) was disbanded early in 1973, guerrilla forces continued to plague the military, and at one point these groups threatened to kidnap the daughter of U.S. Vice President Sipro Agnew. The only other major military activity was that of the U.S. jets being sent to Brazil (mentioned above). This purchase (and other purchases of U.S. weapons) were seen by some within Brazil as a way to continue to oppress the people.

When Geisel entered the Presidency in 1974, he promised a relaxation of military censorship over the media, though this did not last long. He also made it known that the military was his number one priority. 
Labor - - Strikes and Unemployment

Worker unrest and strikes were a factor in the national landscape, though militant unions and strikes were illegal during the period under discussion. There is no quantifiable data for strikes during this time. Several work stoppages were reported, though the reports were censored. Reports of such work stoppages did point out that most took place in the modern sector, a sector heavily saturated with foreign-owned MNCs, including pulp and paper mills -- the industry used to gather data for Brazil (Sandoval, 1993).25

The Roman Catholic Church played a major role in the worker uprisings. The church continually accused the government of perpetuating low wages and poor living conditions for much of the population. They even said that workers were ready to physically confront the government if necessary.

\section{Quantitative Data}

TABLES VIII, and IX and contain the quantitative data for Brazil (page 78).

${ }^{25}$ To give an idea of the political landscape of Brazil during the years under investigation, in 1972, 18 deaths were reported along with four disappearances: 1973, 16 deaths and seven disappearances; 1974, 0 deaths, 13 disappearances (Sandoval, 1993). 
TABLE VIII

GNP AND GNP PER CAPITA, BRAZIL 1970-1974 26

Year

$\begin{array}{cc}\text { GNP(millions U.S.\$) } & \text { GNP per capita(U.S.\$) } \\ 38,470 & 420 \\ 44,260 & 460 \\ 52,010 & 530 \\ 76,950 & 760 \\ 97,250 & 940\end{array}$

TABLE IX

UNEMPLOYMENT FIGURES, BRAZIL 1970-1974 27

Year Population

\# of unemployed ( $x$ 1000)

1970

1971

1972

1973

1974

$$
\begin{array}{r}
92,237,570 \\
95,170,000 \\
97,850,000 \\
100,560,000
\end{array}
$$$$
725.0
$$$$
723.0
$$$$
1,033.9
$$

968.0

Hypotheses, Predictions and Data for Brazilian Workers

I turn now to the supporting hypotheses.

- The first, that if national leaders express

positive attitudes toward foreign investment and/or intervention, then workers will show positive attitudes toward foreign-owned MNCs, would predict positive attitudes. Brazilian leaders between 1972 and 1974 were heavily in favor of foreign-owned MNCs, seeing these organizations as essential to continued economic growth.

\section{${ }^{26}$ Source, World Bank Atlas, 1972-1976.}

27 Source, wilkie (1980). Brazil did not report unemployment rates during these years, though from 1970 to 1973 the number of unemployed workers was reported. For this reason, I will give population and unemployed figures for each of these years. No figures were reported for 1974. 
The sentiment of U.S. domination expressed by Horowitz seems to either have been reified or dissipated within the ten years between his writings and the time under study. Also, other countries were openly courted for economic reasons.

- The second supporting hypothesis, that if the country were experiencing either inward or outward military intervention, then workers would have negative attitudes toward foreign-owned MNCs, would show that there was little activity (that involved another country) in this area for workers to be concerned.

- The third supporting hypothesis is blurred in this case. If a country experienced over 200 strikes during any of the years under study, then workers would view foreignowned MNCs as negative. Unfortunately, strikes were illegal, and worker unrest and strikes during this time were not reported. It is probably safe to say that in no year were there 200 strikes, but this may not be due to worker satisfaction, but due to the legality of strikes. It would seem that workers were not too unhappy, since there were no major worker riots during this time, but this cannot be backed by fact.

- The fourth supporting hypothesis, that if GNP was rising, then workers would have positive attitudes toward foreign-owned MNCs, anticipates positive attitudes within the working class. GNP grew each year by over ten percent. Plus, Brazil was praised as having the highest rise in GNP of any major nation in 1973 (reported in 1974). 
- The fifth supporting hypothesis, that if GNP per capital was shrinking or not growing as fast as GNP, then workers would have negative attitudes toward foreign-owned MNCs. As can be seen, GNP per capita was not growing as fast as GNP, though it was not too far behind. Based on this, workers would be predicted to have negative attitudes, though they would not be extreme.

- The sixth supporting hypothesis states that if unemployment rates are high, then workers will have positive attitudes toward foreign-owned MNCs. Though unemployment statistics for Brazil (and any developing country) are suspect, it is true that unemployment was high during the time under investigation (and continues to be so). Since foreign-owned MNCs were offering employment in an environment of high unemployment, workers would be envisioned to have positive attitudes toward foreign-owned MNCS.

By combining the above hypotheses (leaving out the third), it would appear that workers in Brazil would espouse positive attitudes toward foreign-owned MNCs. This is what was found by Blake and Driscoll (1982). They asked Brazilians who were directly and indirectly employed by two U.S.-owned paper/pulp mills ${ }^{28}$, as well as other Brazilian nationals, about the impact of the mills on the local communities. TABLE X (page 81) contains their findings.

${ }^{28}$ The two mills were owned by olinkraft and Westvaco. 
TABLE $X$

ATTITUDES TOWARD COMMUNITY IMPACT OF TWO U.S.

PAPER/PULP MILLS OPERATING IN BRAZIL (percentage) 29

Plant \# of Respondents Very Positive Positive
Olinkraft
119
61.4
37.5

Westvaco

108

84.4

14.3

Their findings leave little question as to the importance of these two paper/pulp mills to the Brazilian citizens. TABLE XI contains the percentages of respondents who found different aspects of the mills to have positive impacts on their communities when asked about the mills in open-ended interviews.

TABLE XI

POSITIVE ASPECTS OF COMPANIES' EFFECT ON COMMUNITY (percentage)

Aspect

Percentage of responses $(n=290)$

Employment

Adds to community life

Industrial development

Taxes and other services

Generates other business

Positive work environment

Technology transfer

Reforestation

Provides products
37.9

16.9

14.5

9.0

6.6

$4 \cdot 8$

4.5

3.1

2.8

These findings can be compared with responses to negative aspects of the mills in TABLE XII (page 82). 30

${ }^{29}$ All Tables dealing with the Brazilian workers can be found in Blake and Driscoll (1982). Also, percentages may not be equal to one hundred due to rounding.

30 The open-ended interviews asked respondents to discuss both positive and negative aspects of the mills. A majority of the respondents then had to be asked again 
TABLE XII

NEGATIVE ASPECTS OF COMPANIES ON COMMUNITY, STATES (OF BRAZIL) OR BRAZIL

Aspect

No harm

Pollution

Don't know, no answer, or neutral

Local problems

only one kind of tree replanted
Percentage of responses $(n=195)$

46.7

30.8

16.9

3.6

2.1

There can be very little doubt that there are both quantitative and qualitative differences between the Ford Canadian workers and the Brazilian paper/pulp mill workers. The Brazilian workers were skewed heavier to one side of the scale of attitudes toward foreign-owned MNCs than the Canadian workers, i.e. there seemed to be a larger consensus among Brazilians in regards to foreign-owned MNCs. And, of course, the Brazilians were much more positive towards foreign-owned MNCs than the Candians. Does this mean that Brazilians are less nationalistic than Canadians? To answer this question, I need to return briefly to the label "nationalism." If nationalism is considered a type of group paranoia, as Kis (1992) seems to think, then the Canadian workers could be considered more nationalistic (more negative toward inward foreign investment). If nationalism is an expression of national pride (as in the Brazilians' support for their national soccer team) and well-being (no matter what the means),

about negative aspects only, as they would only talk about the positive aspects. 
then no such assumption can be made. ${ }^{31}$ Instead, the idea that working for a foreign-owned MNC could exacerbate nationalistic feelings can again be tested with the Brazilian study. All categories of Brazilian respondents were in favor of the foreign-owned MNCs, but when attitudes of employees and suppliers were compared to those not employed (directly or indirectly) by the MNCs, the former were much more positive on most aspects of the MNCs (not all the differences were statistically significant, though in all cases the employees were more positive). Is there then a MNC effect, as the two cases presented so far suggests? I now turn to the third group of workers -- West German managers employed within MNCs, to see if the pattern continues.

\section{WEST GERMANY}

\section{General History}

At the end of WWII, a person evaluating nationalism within West Germany would probably have said that Germans were too nationalistic and nothing would change them. This

${ }^{31}$ It is hard to have much confidence in studies that show that nationalism is evenly distributed throughout society. In a study done in 1948, in which people were asked if their country held the greatest opportunity to pursue the "good-life," responses ranged from ninety-six percent in the U.S. to thirty percent in West Germany (Doob, 1964). Obviously these responses were tempered by temporal factors, yet it shows the large differences such abstract (though real) attitudes can take across society, not only in the number of people who are nationalistic, but the intensity of nationalism as well. 
could have been based on the fact that Germany had been the aggressor in two major wars (WWI and WWII) within the past twenty-six years (from the beginning of WWI to the end of WWII), with their end goal being global domination (as well as racial domination in the latter war). This nationalistic image could be further increased by the split between East and West Germany, making west Germany the first line of defense against the Warsaw Pact countries. 32 Though West Germany may have had many reasons to be nationalistic, she seems to have been trying, since the end of WWII, to shed her past image, as can be clearly seen in her ostpolitik. 33 shortly after WWII, West Germany's postwar Chancellor, Konrad Adenauer, told the French (Germany's long-time rival) that Germany's fate was tied to that of Western Europe (Pfaff, 1993). West Germany was given back its sovereignty in 1955 (Stahl, 1963). Since then, West Germany has been the driving force behind the European Economic Community (EC).

The rise of West Germany's economic strength can be tied to the U.S. Marshall Plan which helped rebuild West

${ }^{32}$ It should be noted that this split was not brought about by the German people, but by the ideologies of the leaders of NATO and the Warsaw Pact. Though West Germany is a member of the former and East Germany was a member of the latter, their roles were manipulated by other members of the pacts (Kennedy, 1987). This became evident when both Germanys celebrated the falling of the Berlin Wall.

${ }^{33}$ ostpolitik is a policy or agenda aimed at reunifying the two Germanys, as well as European reconciliation in economic and political affairs (Jones, 1991). 
Germany's industrial infrastructure after WWII (Stahl, 1963). Since that time, west Germany has become one of the most prosperous nations in the world (Brockway, 1963), and the third largest producer of motor vehicles in the world (Maxcy, 1981).34

Though West Germany is (or seems to be) trying to shake its nationalistic reputation, it has not always been helped by its Western European neighbors. In the 1970's there was a push in West Germany to create more MNCs within Western Europe, but the effort was met with stiff resistance - mainly in the form of nationalism and "Germanphobia." There were some exceptions, such as Volvo, but for the most part foreign-owned MNCs were seen as neocolonialistic (Maxcy, 1981).

\section{Politics}

By 1974, West Germany had the largest economy in Europe, along with a low unemployment rate (1.6\%) (Kearl, 1993), 35 but this was rising and workers were threatening nationwide strikes. West Germany also boasted a record trade surplus of $\$ 10.8$ billion, which was helped by 2.6

${ }^{34}$ The reason I focus on automobile manufacturing is that this is an industry that not only gives some idea of the strength of a nation, but also tends to be suited for multinational endeavors. If a country has a strong automobile sector, it is probably a strong home nation for MNCs. The facts seem to support this, as the U.S. is number one, Japan second, and West Germany third. All three have many home-based MNCs.

${ }^{35}$ West Germany had the second lowest unemployment rate of any major country in 1974. Japan was lower at $1.4 \%$. 
million foreign workers. West Germany was home of the second largest military force in NATO, and she had the founder of ostpolitik, Willy Brandt, as her Chancellor -until March.

West Germany was rocked by the resignation of Chancellor Brandt in $1974 .^{36}$ Brandt had been elected Chancellor in 1969. During his time in office he continually pushed for German reunification, a unified Europe (in the form of the EC), and detente with the U.S.S.R. and other Eastern European nations. Before he left office in March, Brandt backed an agreement that gave West German and U.S.S.R. entrepreneurs the chance to join forces in setting up joint companies in Third World countries. In spite of these events, some thought his efforts to build relations with the U.S.S.R. had slowed down by this time. Brandt felt that talks would only succeed if the ideological barriers between East and west were dropped. Brandt was also planning on increasing West German purchases of other EC partners' products to help boost their economies. He oversaw the passage of a bill that gave West German workers a larger voice in business (a move from one-third of representation on company boards to one-half) and a newly created government-run system of profit-sharing. Though workers and labor leaders hailed this new law, business leaders said it would be too

${ }^{36}$ As was East Germany. 
expensive. This concern was echoed by U.S. businesses operating in West Germany, which, in turn, gave West German governmental officials a reason to accuse these U.S. business leaders of meddling in west German affairs.

Brandt's resignation was brought about, in large part, by an East German spy scandal that originated in Brandt's office. Whether a spy scandal would cause citizens to become more or less nationalistic is open to debate (it seems that this could be the basis for strong nationalism, as one country would see another as meddling in its affairs and jeopardizing its security), it did give officials of the U.S.S.R. a chance to issue a report that this was a major setback to East-West detente. Not only was the spy scandal a setback, but Brandt was the one western leader who had forged personal ties with U.S.S.R.'s leader Leonid Brezhnev.

Brandt was succeeded by his Finance Minister Helmut Schmidt. Schmidt was expected to be friendlier to business than Brandt, but many were not sure what his foreign relations policy would be. Shortly after entering the Chancellor's office, Schmidt made it clear that he would continue Brandt's policy of Ostpolitik.

Relations with the U.S. were nurtured by schmidt. He had visited the U.S. before becoming Chancellor, and traveled there again in December. He was pushing to have the U.S. follow West Germany's move to drop antiinflationary policies and focus instead on unemployment issues, and even welcomed U.S. investments. Schmidt sent 
officials to Washington D.C. to discuss military issues. Schmidt seemed more inclined to having a strong military presence in West Germany than did his predecessor. Even in his inaugural address he made a plea for U.S. military and political presence in all of Europe, saying NATO was the heart of Europe's and West Germany's security. An agreement expanding cooperation in environmental matters was also signed between the U.S. and West Germany. The U.S. sent Secretary of State Henry Kissinger to west Germany to continue talks on economic and defense issues. One area of contention between the two countries arose over the activity of the CIA. West German officials viewed CIA operatives in West Germany as acting without their consent. When lists of spies were made known to West German officials, it always came after investigations had been done.

Schmidt visited the U.S.S.R. within his first year as Chancellor, actually visiting there before traveling to the U.S. His talks centered around long-term economic cooperation and trade. With the U.S.S.R. rich in natural resources, such as oil, coal, and natural gas -- resources needed by an industrialized country -- and west Germany rich in technical knowledge -- something needed by the U.S.S.R. -- cooperation made good sense. The only problem was the land between the two countries. Nations within this area, especially East Germany, did not want power and transportation lines linking west Germany and the U.S.S.R. running across their lands. U.S.S.R. officials traveled to 
West Germany at this time to continue talks over the impasse.

Relations with France were expected to improve after three hundred years of animosity. One reason for this optimism was that both countries had new leaders. West Germany had Schmidt, while France had a new President, Valery Giscard d'Estaing. The two leaders did meet, but Schmidt found d'Estaing a weak leader, or at least mentioned that he did not have enough domestic support in France to help West Germany unify Europe. Relations became strained once again. 37

East Germany and West Germany seemed to be locked in a love-hate relationship. Though they exchanged permanent representatives, East Germany removed all mention of German reunification from its constitution. The two countries even bickered over the ownership of museum pieces. These pieces had been displayed in what became East Germany before WWII, but had been moved to West Germany by war's end. Still, from the west German point of view, the emphasis was on reunification.

The final foreign relations aspect of 1974 involved Middle East countries. When Kuwaiti investors bought

${ }^{37}$ This should not have come as a great surprise. While still Finance Minister, Schmdit was backing pressure from the U.S. on France to follow U.S.-generated energy policies within NATO. France was apprehensive, feeling that this would be a buckling to U.S. domination. France was also being overlooked for help in European unification during this time. Once again, the country looked to was the U.S. 
fourteen percent of Daimler-Benz, West German officials and business leaders began calling for tighter controls over foreign investments. These officials knew the importance of Middle Eastern oil, but this very importance generated concern. The dependence on foreign oil had been an area of concern for all industrialized countries after WWII, and now the dollars being spent for that oil were showing back up as petrodollars in West German companies. Schmidt did say Arabian investors were welcome, but the cry for control over foreign investments would get louder in 1975.

There were two internal political events (other than Brandt's resignation) that took place in 1974 that may have had an effect on nationalist attitudes. The first was the formation of a new right-wing political party (Union of Free Germany) that was to attract nationalists and other conservatives. Though the party opened with only about 300 members, it was reported that another 20,000 West Germans had expressed an interest in joining. The second event was the discontinued observation of the anniversary of the June 17, 1963 uprising of workers in East Germany. This day had been seen as the day of unity for the two Germanys. Schmidt was heavily criticized by workers and labor leaders for his part in this matter. 38

${ }^{38}$ This criticism was no doubt louder based on the fact that Schmdit had promised to continue Brandt's reunification policies. 
Relations with East Germany continued to be on unstable ground in 1975. Opposition leaders in the west German government wanted Schmidt to refuse to sign the closing Declaration of the European Security Conference because they felt it did not guarantee the right for the future reunification of the two Germanys. East German spies continued to plague West German security circles, and kept NATO officials uneasy. 39 schmidt, meanwhile, continued to emphasize the need for strengthening relations with East Germany (and other Eastern European countries), saying it was fundamental to West German foreign policy.

Middle East investors continued to concern West German officials as money continued to pour in from Kuwaiti and Iran. Bills were proposed to curb such investments (especially in sensitive sectors), though these bills were written so as to not affect investments originating in OECD member countries. 40 This Middle East xenophobia was certainly evident when a six man Saudi Arabian delegation caused a stir during a west German business conference. 41 Saudi Arabians were also buying West German castles, which

${ }^{39}$ A West German Air Force colonel was arrested for spying for East Germany, and even Willy Brandt's son was held for questioning.

${ }^{40}$ Schmidt went so far as to say that all major western nations, including the U.S., were worried about Middle Eastern investments.

${ }^{41}$ The delegation was not asked to leave, but west German business leaders were visibly nervous about their presence. 
caused alarm in some circles. Schmidt did meet with the Shah of Iran -- a sign that some in West Germany felt the need to keep some semblance of diplomatic ties with these countries.

West German officials were becoming concerned with their U.S.S.R. detente policy, saying that it was beginning to slow, though it continued to be stable. When the U.S. and U.S.S.R. broke off a trade agreement, West German officials were reported to be uneasy, but confident that their position would be safe. West German President Walter Scheel did meet with Brezhnev to discuss exchanges of technical and intellectual information, though little progress was made. These talks did little to solve the continued debate over the border of West Berlin. Voters were also expressing their discontent over recent relations with the U.S.S.R. Some elections were lost over this issue, as West Germans began demanding (with their paper stones) a stronger stance with the U.S.S.R., especially concerning West Berlin. Though voters may have wanted a harder line, some German officials felt otherwise. In a move that some may have considered much too friendly, military leaders in the U.S.S.R. were offered invitations to observe West German military maneuvers.

One country that West Germany continued to turn to was the U.S. During the year, Kissinger met with Schmidt to discuss economic issues (shortly after the two countries and Japan pulled together to ward off pressure from the International Monetary Fund to stimulate their economies), 
Scheel met with Ford to discuss defense issues, and Ford met with Schmidt to coordinate efforts concerning Western Europe's economic programs. U.S. business leaders did cause some waves. Henry Ford II, during a visit to Ford facilities in West Germany, lashed out at the codetermination bill saying it would be bad for business, but the bill still passed. Lockheed was accused of paying off West German officials to promote the sales of its U.S. manufactured aircraft. In addition, an agreement to sell nuclear technology to Brazil was met with stiff resistance (Braunthal, 1977). Still, with the many meetings of top officials ${ }^{42}$ and the presence of U.S. troops in west Germany, U.S.--West Germany relations were strong. In other foreign relations, ties with France did stabilize (for a short time), as Schmidt met again with d'Estaing and agreed on a coordinated economic program. France even ended celebrations commemorating its victory over Germany in WWII. Meanwhile, ties with Poland became strained after Polish officials demanded reparations from West Germany. Relations with Spain were also put under pressure after schmidt sought to block the entrance of Spain into NATO, saying it would be too much of an economic burden. China was courted, as schmidt became the first West German official to visit that country. He signed an

42 Not only did the aforementioned meetings take place, but Brandt also made a North American visit, stopping in Mexico and the U.S. 
agreement after talks with Mao Tse-tung to establish a joint trade commission. Israeli Premier Yitzhak Rabin made a visit to west Germany to discuss issues in his country in which West Germany could have played a part.

Internal politics and activities kept West German leaders busy as they approached a major election year. Over one million workers were unemployed, and a trade surplus of $\$ 22$ billion began to fall. Schmidt did try to appease workers by saying they were the reason behind west Germany's success as a European and world power. Plus, Schmidt was being plagued by terrorist activities, as the West German embassy in stockholm was stormed. This was in retaliation to the holding of terrorists in West German prisons.

Nineteen-hundred-seventy-six was a major election year in West Germany. Schmidt was facing growing opposition from Helmut Kohl and the conservatives. Though he won the election, his margin of victory was very slight (two House votes). During the campaign, Schmidt took every opportunity to win the loyalties of the West German workers, though he did refuse to nationalize West German industry (Braunthal, 1977). Unemployment did drop, though this was still seen as a major problem during schmidt's term. The codetermination law went into effect on July 1 (the elections were in October) which improved Schmidt's position with the workers, but others in the business sector felt that backlashes were inevitable as power was given to the wrong people. In addition, Schmidt said that 
humane working conditions were key to social peace and stability. Still, the narrow victory showed that not all were won over by Schmidt. ${ }^{43}$ This election also showed a rejuvenation of neo-Nazis, who received 120,000 votes (Braunthal, 1977.).

In foreign relations, West Germany found itself once again being accused of interfering with its own economic growth. European neighbors and the IMF began putting pressure on West Germany to boost its economy. In Paris, Amsterdam, and Stockholm people were found to still harbor fears of Germany stemming from WWII, West Germany's growing economic base, and its growing military. The opposition party (Christian Democrats) held Schmidt accountable for these attitudes, pointing to his continuing assertion that West Germany was the leading country in Western Europe. ${ }^{44}$ He did make statements that he was putting West Germany in a position to help other nations with their balance of payment problems.

Relations with the U.S. continued to be strong, with Schmidt saying that relations had developed to the point of being based on mutual trust. His unemployment policies

${ }^{43}$ A move by Volkswagen to begin manufacturing transportation vehicles in the U.S. (to avoid high labor costs and have a stronger market base in the U.S.) did little to help schmidt's campaign with workers. It was seen as an exportation of jobs.

${ }^{44}$ schmidt felt that West Germany was beginning to pull away from the rest of Western Europe due to its growing economic base and an unmatched aversion to communism. 
were seen only to be effective if they were coordinated with those in the U.S., and he traveled there to discuss economic issues, as well as issues pertaining to politics and the military. West Germans even celebrated the U.S. bicentennial as if it were their own bicentennial. U.S. Vice President Nelson Rockefeller and Kissinger made trips to West Germany. An article covering Kissinger's statements on the role of the U.S. in Western Europe's defense was even carried by a special edition of a west German magazine. It was even discovered that the CIA and West German intelligence officials had been working closely together, though this did not make all west Germans happy. One issue that caused growing tensions among governmental officials was over developing a standardized military tank. Though the two countries did finally decide on some common components, 45 both accused the other of unfair competition. The U.S.S.R. and west Germany continued their onagain-off-again relations. The former accused certain members of the latter of undermining relations, though Brezhnev did make a visit to West Germany. East German officials remained undecided over West Germany. Their new five year plan did not include any references to unification, but did envision normal relations. Relations with France continued to be apprehensive. Schmidt and d'Estaing met to discuss West Germany's industrial base,

${ }^{45}$ The U.S. was to use West German guns, and West Germany was to use U.S. engines. 
which d'Estaing felt was very strong. But, Schmidt further strained relations by saying he was worried about growing communist influences within France. d'Estaing, in possible retaliation, said that France must build its military to counter both the U.S.S.R. and West Germany. Finally, China stepped up its relations with West Germany by increasing trade to $\$ 725$ million, and backing a unified Western Europe to balance the U.S.S.R. ${ }^{46}$

\section{Military Activities}

Being the NATO border country meant that military activity would be a large part of the West German political and social landscape during the three years under study. Activity in this area was so pervasive that at times it seemed much more important than reunification or detente. West Germany stressed NATO and EC solidarity, and in 1974 both Brandt and Schmidt were adamant about NATO forces in West Germany. West German officials at one point even traveled to the U.S. to discuss measures for reviving NATO forces and morale. Agreements were made between West Germany, the U.S., and Canada to pursue common components for military weapons in a move to standardize NATO forces. These three countries also had 41,000 troops participating in joint military activities in west Germany as a show of strength and solidarity. The only negative was that U.S.

46 There was other West German foreign relation action, though most of it consisted of a meeting (Great Britian) or a couple of statments (Angola). 
troops stationed in West Germany were criticized for being in the wrong place. West Germans felt that these troops had not adjusted to new Warsaw Pact capabilities that had changed invasion tactics and routes.

In 1975, West German military leaders became anxious after Warsaw naval activity in the Western Baltic Sea increased. Plus, they were concerned with the strength and stability of Turkey, and met with Turkish officials to discuss their worries. Portugal's seemingly turn towards communism also put West German leaders on edge, as did talks from the U.S. over reduction of nuclear missiles and a forty-six percent drop in exports (nation-wide) to the U.S. This latter issue was the start of talks over a possible economic recession in the U.S. and what that would mean to West Germany's capability to defend itself in case of an attack. This led Schmidt to confer with U.S. President Gerald Ford about NATO economic unity. West Germany made a $\$ 32.3$ million weapons purchase from the U.S as well. Additionly, West German officials were worried about possible U.S. troop withdrawals, though this did not happen. As a matter of fact, the U.S. sent a brigade to the North German plain to take up a permanent position. Not all West Germans were happy with this, as 15,000 signed a protest petition. Contentions began to run high concerning NATO weapons standardization. West German officials accused U.S. officials of preventing open competition between military tank manufactures from the two countries. 
West German officials got little relief in 1976. They were still weary of the Warsaw Pact countries, though they did feel that NATO could match this power. ${ }^{47}$ west Germany continued to buy weapons from the U.S., spending $\$ 43$ million on U.S. military hardware. Though they were willing to pay this amount, they did balk at the prospect of buying $\$ 2.44$ billion AWACs (Airborne Warning and Control System). Also, when the Warsaw Pact countries forwarded a proposal to mutually defer the first use of nuclear weapons and put a freeze on memberships into both pacts, West German officials opposed it.

Labor -- Strikes and Unemployment

Due to the strong ties between politics and labor within West Germany, it was difficult to separate the two areas (as can be seen by the discussion under the political subheading). At this point, I just want to reiterate a few key points. First, support for the codetermination bill was given by both workers and governmental leaders, but opposed by business leaders (both domestic and foreign). Plus, possibly to appease some of the business leaders, more managers were to take part in the boards created by the bill (this move was opposed by labor groups). secondly, remember that unemployment was rising at this

${ }^{47}$ This may have been based on the assumption that if war did break out between the two blocs, that there was enough firepower on each side that both would be eliminated. 
time -- something that West German workers had not experienced since the end of WWII. Finally, one of Schmidt's main re-election platforms was for safe, clean, humane working conditions.

\section{Quantitative Data}

TABLES XIII, XIV, and XV contain the quantitative data for West Germany.

TABLE XIII

GNP AND GNP PER CAPITA, WEST GERMANY 1972-1976 48

Year

1972

1973

1974

1975

1976

Year

1972

1973

1974

1975

1976 GNP (millions U.S.\$) GNP per capita (U.S.\$)

$$
\begin{aligned}
& 208,970 \\
& 329,670 \\
& 389,760 \\
& 412,480 \\
& 461,810
\end{aligned}
$$

3,390

5,320

6,280

6,670

7,510

\section{TABLE XIV}

UNEMPLOYMENT RATES, WEST GERMANY 1972-1976 49

Unemployment rates

0.7

0.7

1.6

3.4

3.4

${ }^{48}$ Source, World Bank Atlas, 1974-1978.

${ }^{49}$ source, Kearl (ㅇp. cit.) 
TABLE XV

STRIKES AND WORK STOPPAGES, WEST GERMANY 1974-1976 50

Year

\# of strikes (betroffene betriebe) ${ }^{51}$

1974

890

1975

201

1976

950

Hypotheses, Predictions, and Data for West German Managers

I now move to my supporting hypotheses.

- The first (national leaders) would predict workers expressing positive attitudes toward foreign-owned MNCs. Though not all West German leaders pursued greater foreign relations, the overall policy of ostpolitik of both Chancellors was pursued by most West German leaders. If workers saw these leaders as representing West Germany, then they would be behind this policy as well.

- The second supporting hypothesis (military intervention) is complicated in west Germany. Though no overt military action was taken by the West German military, there was definitely a foreign military presence at all times. Not only was a large (and growing) U.S. military contingent stationed in west Germany, there was also the fact that their closest neighbors to the east were Warsaw Pact countries. One would be hard pressed to say

${ }^{50}$ Source, Arbeits-Und Sozialstatistik (1978).

51 These numbers should be qualified. West German strike activity was actually low compared with other industrial nations. The numbers reflect not only actual strikes, but also worker grievances that did not end in actual strikes. 
that these factors would play no part in the attitudes of West Germans, so I would have to say that this would make West German workers anxious, and, therefore, espouse negative attitudes toward foreign-owned MNCs.

- The third supporting hypothesis (worker unrest and strikes) would have workers expressing negative attitudes toward foreign-owned MNCs (the only year that had less than 500 strikes was 1975). Remember, strike activity (as we know it in the U.S.) may not be accurately reflected in these numbers.

- The fourth supporting hypothesis (GNP) would put workers in a positive mood toward foreign-owned MNCs, as GNP rose each of the five years.

- The fifth hypothesis (GNP per capita) would predict positive attitudes as well, as GNP per capita kept pace with GNP.

- The sixth supporting hypothesis (unemployment) would not predict positive attitudes, as the unemployment level each year was under six percent. This should be qualified, though, since the rates of unemployment were growing (at least in 1974 and 1975). Unemployment was also a major factor in elections during the years under study, so it could be said that though unemployment did not go over six percent, workers were worried about the prospects of unemployment -- foreign-owned MNCs may have been offering jobs.

Combining the six supporting hypotheses gives a complex picture of possible attitudes. Though the overall 
foreign policy of West German leaders was one of openness, the military activity happening in and around west Germany could not have been ignored. And, though GNP and GNP per capita were rising, so was unemployment. Strike activity was high, but at the same time lower than other industrial countries.

This complexity showed in Sauvant and Mennis' study. Sauvant and Mennis did not study blue collar workers (as did Marton and Blake and Driscoll). Instead, they distributed questionnaires to 3,300 low-level managers and other white collar workers employed within foreign-owned MNCs operating in West Germany, West German-based MNCs, and businesses operating in west Germany only. They did not specfically ask these workers if they were for or against foreign investments, but instead tried to discern whether the workers in the different types of companies were ethnocentric or internationally focused, and if there was a significant difference between the groups. Questions pertaining to such issues as affiliate orientation (who should control MNC affiliates), EC goals of integration (including possible personal financial sacrificies to achieve integration), and the attitudes toward foreign workers were posed to the respondents. None of the statistical findings were significant when workers from the different categories were compared to each other.

These findings led Sauvant and Mennis to conclude that employment within MNCs had no effect on workers, though I think this may not be correct. It may be that they found 
no effect in West German workers, because of the national context within which these people lived. It may be that white collar workers are less inclined to be affected by whom they work for than are blue collar workers. It may even be a combination of these. This is based on the survey reported in Chapter II, in which U.S. non-elites and elites differed on their attitudes toward foreign investment. I do not think that all the workers surveyed would be considered part of the west German elite, so this possibility is minimal. It is more likely that there was a national variable that was unaccounted for within the Sauvant and Mennis study.

\section{POSSIBLE DISCREPANCIES}

Before moving on to my conclusions, I think it is imperative that I discuss some possible shortfalls of this study. First of all, the choices of possible independent variables to study in this area are almost endless. The six chosen, as mentioned in Chapter IV, were ones that I felt would have an impact on the working class of a country. Other possible variables include export-import balances, value-added averages in MNCs, population growth, GNP of neighboring countries, type of government in the countries under study, wage differentials between MNCs and non-MNC firms. 52 The list goes on, and each variable could

52 Due to time restraints, I was not able to gather data on wages in the specific firms that were studied. It has been shown, though, that the average foreign-owned MNC 
probably explain some of the variance within and between the studies, but a line has to be drawn at some point. Though I chose my line carefully, that is no guarantee that it was drawn in the right place.

A second possible discrepancy is the fact that the same questionnaire was not used with each group of subjects. Though each questionnaire was tested for validity and reliability by those administering the questionnaires and interviews, this does not mean that they each measure the same attitudes in the same way.

A third possible shortcoming is that the West German study was done across industrial sectors, while the Canadian and Brazilian studies were done in specific sectors (the former in a specific plant). It may be that if all sectors had been studied in each case there would be an 'averaging' influence. It was noted in chapter III that not all workers are going to have the same attitudes toward work because of the nature of their work. It is possible that if the studies in Canada and Brazil had been coupled with questionnaires from the service sector (banking, real estate, etc.), then there would be greater differences (and so an 'averaging' of attitudes) between workers. This may

wage is higher than home-based firms, though this may not be a significant difference (see Chapter II above, and Caves, 1982 [esp. pg. 151-153], though see Banaji and Hensman (1990) for an example of wage differences between home and foreign affiliates of the same companies [TABLE $3.4, \mathrm{pg}$. 73]). 
be true in the case of Canada, ${ }^{53}$ but hard to visualize in Brazil. The workers questioned were employed within paper/pulp mills, but still found pollution not be a problem. It seems that foreign investment was so welcomed in Brazil that workers within any sector would have viewed it positively.

Finally, though causal linkages were sought and the possibilities of such linkages discussed, the methodology used in this study does not give sufficient evidence to discern specific causal chains. The above data analysis is meant to give plausible agruments for the possibility of linakges between societal factors and workers' attitudes toward foreign-owned MNCs. Participant observations and quantitative tests (more interviews and questionnaires administered at neutral sites) are needed to supplement the findings found within the body of this text. I do not see this study as a finished piece, but as a gateway to a better understanding of societal influences on foreignowned MNC workers.

${ }^{53}$ Though it should be noted that many in Canada were trying to keep foreign investment out of the service sector (see the discussion under Canadian Politics above). 
CHAPTER VI

CONCLUSIONS AND RECOMMENDATIONS FOR FURTHER STUDIES

MNCs are human institutions. They are started, managed, and carried on by humans. Like all human institutions, they are more than just the sum of their parts. For this reason, it is only the myopic researcher(s) who says that those working within such institutions will not be affected. Unless the workers are robots, $^{1}$ they will be affected in some way, whether this is an entrenching of nationalistic pride or an acceptance of a foreign presence. Which will happen will depend largely on the culture in which the workers live. These cultures are not static or ahistorical. As Peter M. Senge said, when we break our society into pieces "...we lose our intrinsic sense of connection to a larger whole," and cannot "reassemble the fragments...." (1990, pg. 3). To understand MNC workers and predict their attitudes toward their working environments, we must take into account societal aspects such as those investigated within this

${ }^{1}$ It may be that they do not know their company is foreign-owned. This type of scenario is definitely worth studying - - why are they not aware of the nationality of their employer? Is it ignorance on part of the worker(s), or a hidden agenda on the part of the foreign owner(s)? 
study. Workers are not just employed; they have families, life histories, educations, friends, coworkers, national leaders, financial situations, favorite radio and/or television programs. In other words, they live within communities -- within society. And like institutions, society is more than the sum of its parts. This should be made clear by the different findings of the researchers reported within this paper. There was one business practice investigated -- foreign-owned MNC -- in three different countries, with the result being that a majority of the workers in each group espoused an attitude towards MNCs that was different than the other groups. (A majority of the Canadian workers were opposed to foreign-owned MNCs, a majority of the Brazilian workers were in favor of foreign-owned MNCs, and a majority of the west German managers showed little or no preference between foreignowned MNCs, domestic-owned MNCs, and West German-only businesses.)

This brings me to my main hypothesis, which stated that if a person is employed within a foreign-owned MNC, then he/she will have a positive attitude towards foreignowned MNCs. This is obviously false since a majority of the Canadian workers were opposed to foreign investment. What does this mean for the MNC effect, if it exists? First of all, I do think it exists. Very few people working within this environment can be unaffected -- work is too important to people's lives. Secondly, I think that the MNC effect is exacerbated by societal factors (and vice 
versa), one of the strongest being nationalism with national leaders' statements and military activities being strong candidates for possible predictors of overall nationalism within a country. Other societal factors, such as unemployment rates, strike activity, and overall economic strength of a country will also play a role in shaping the workers' attitudes. This explains the different attitudes of the workers in the different countries -- each population had experienced different societal circumstances.

Let me now turn to sociological theory. I have already discussed the strengths and weaknesses of sociobiology and exchange theory (Chapter II), and rejected both in favor of social identity in which to approach and predict the attitudes of the MNC workers. Though I chose the social identity approach as the best theory in which to ground the predictions, other sociological theories are relevant and precursors to social identity. This approach has borrowed material from both functionalism and conflict theory. I will briefly discuss the contributions of these two theories to social identity and the study of MNC workers.

As I noted in the second chapter, social identity theory is based on the idea that individuals seek out group labels that they feel would give them a positive self identification. This takes as given that society is structured in social categories, and that the labeling of the different groups serves the function of ordering a 
potentially chaotic social world. By studying the workers within a social and cultural system, social identity is also seeing these latter systems as functioning to internalize values and beliefs within the workers. This is obviously borrowed from functionalism -- mainly Parsons' work on integration among systems of action. Functionalists would also point to the foreign-owned MNCs in Brazil as examples of functional economic integration; not only were the foreign-owned MNCs welcomed by the majority of the MNC workers, these firms brought jobs and economic strength to Brazil, and furthered global economic integration. Since economic integration is an essential element of society to most functionalists, this is a strong argument for using functionalism to predict the course of workers' overt reaction to foreign-owned MNCs.

Functionalism, though, cannot easily predict which group label(s) is going to provide positive self identification, especially when more than one strong label (such as nationalism and working class) are in contention. Since many labels and, therefore, groups are in contention within society, ${ }^{2}$ social identity borrows heavily from the conflict perspective, more so than from functionalism (Hogg and Abrams, 1988). It is important to keep in mind that, according to social identity theorists, social categories

${ }^{2}$ Not all groups are opposed to each other, though the thread that holds them together is (usually) rather weak. cooperation between groups is as important to the study of groups as is hostilities. 
are not in harmony, but divided by deep differences in values and beliefs. The groups falling within the different categories will, in many cases, see the other groups as obstacles to obtaining positive identifications. For example, in the Canadian study a majority of the MNC workers had negative attitudes toward foreign-owned MNCs, a fundamentally opposed viewpoint to that of their employer. Even groups within Brazil were experiencing conflicts, such as that between the Catholic Church and the Brazilian government over the treatment of the indigenous population living within the rain forests. This can be generalized to other circumstances as well. A nationalistic worker in a foreign-owned weapons manufacturing company may be very unhappy with the foreign investment (or any type of company that is foreign-owned). Of course if jobs are scarce, or the worker is a strong international union advocate, the attitude towards foreign-owned MNCs may change. Would the opportunity of employment be enough to change the mind of the nationalistic worker, or, for the latter individual, will the foreign firm be seen as an opportunity to begin to network internationally with fellow workers? Social identity is a better predictor of actual attitudes (which will be explained further below), while conflict theory would predict the course the workers would take in dealing with the presence of foreign-owned MNCs.

Conflict theory and functionalism are both macro theories, and so do not adequately explain microprocesses. Social identity theory is flexible enough to take into 
Social identity theory is flexible enough to take into account both historical and immediacy effects, and looks for explanations of group label choices through the group within the individual making it more than a micro theory. 3 This also alleviates the problem of tautology. Social psychological theories (and other microsociological theories) have been marked as tautological by some (e.g. Turner, 1987). These critics would ask whether the group label has been chosen because it is good, or whether the group label is good because it has been chosen. Using social identity theory, I would say it is most often the former, though there is a dialectic between the two forces. Let me return to the MNC workers. Workers are going to fall somewhere on the continuum of either welcoming or despising the foreign-owned MNC. Their placement on this continuum will be welcomed by others who share the same (or close to the same) attitudes, but unwelcomed by those who have opposing attitudes. In other words, a person's (or group's) attitudes will always be opposed by another person (or group). The stance (label) chosen was done because it was seen as offering a positive self identification. Group labels are most often chosen for their positive self

${ }^{3}$ This is not to contradict the above statement that conflict theory could be a better predictor of an ingroups' reaction to an out-group (s). What social identity theory could be used to predict beyond microprocesses is the possible out-groups targetted for hostilities (these would not have to be overt hostilities, but could be nothing more than verbal assaults within the in-group. 
identification, not that they are good because they are chosen. 4 This gives social identity theory -- when combined with sociohistorical factors -- a strong predictive ability that does not have to be relegated to individuals.

To move beyond the microprocesses of social identity theory takes only the knowledge that humans are social animals. Groups that fail to attract new members (for whatever reason $)^{5}$ will become nonexistent (e.g. American Party), while others that gain new members ${ }^{6}$ may grow extremely large (e.g. Christianity). This ability to explain both micro- and macroprocesses makes social identity theory a theoretical approach that needs to be intensively studied and tested, especially when used in

${ }^{4}$ This is not to say that some people choose labels because they want to be part of the in-group. Music and fashion fads ("pop" fads) are a good example of this. Many people will listen to a certain style of music or wear a certain style of clothes to feel like they are part of some group. What needs to be pointed out here is that the music and other fads are not the primary labels; the primary label is to be part of a certain group.

${ }^{5}$ There could be many reasons for a group to fail to attract new members, such as being overly secretive or such an anomaly that very few people are interested in becoming a member. It may be that cases of the former could have given many people the possibility of positive self identification, but that the founding members were so protective of their group that they let no one else join. Small membership in such groups should not be seen as a rejection of social identification theory, but as an example of why freeze-frame studies need to be accepted with careful regard.

${ }^{6}$ Gains can be made from recruitment or an "open-door" policy for new members. 
combination with conflict theory. There are many institutions which can be investigated. The MNC is just one type of empirical institution which lends itself to the testing of social identity. More research needs to be done on attitudes before employment begins, and how these attitudes may change during employment. Also, studies need to be done on the steps taken to accommodate the MNCs or the negative attitudes toward the MNCs (is there a workers' backlash against the MNCs -- are strikes at MNCs more violent than strikes at other companies -- or are they finding positive identifications somewhere else?). In other groups, such as gangs, social identity could be tested by gathering information on why the members joined the gang (and why they continue to be a part or drop out). If "gang" status is unfulfilling to the members, yet they continue to be members, then social identity should be replaced by another theory, such as exchange theory if the members are only staying in to reap capital rewards. 7 Finally, I would like to return to the MNC one last time. I started this paper with a statement about the world shrinking and expanding at the same time. To become a truly global community, we must stop the expansions.

7 This finding, though, would be problematic. If the capital rewards were the basis for positive self identification, then membership could be explained by social identity -- the capital rewards (and the symbols these bought) were more important to the positive self identity than the gang membership was to the negative self identity. 
MNCs may be a key to furthering the understanding of different cultures, and, therefore, a key to a more peaceful global community. But, we must begin to investigate the processes of social distance and nationalism within the MNCs with more attention paid to spatial and temporal factors within society. Sociology and other social sciences must move beyond freeze-frame investigations, though this does not mean we have to go back to the origin of man for every study (which would be ludicrous). What needs to be done is to gain a more thorough understanding of the background of present human interaction and action. As it has been said, the best predictor of what happens today is what happened yesterday. 
REFERENCES CONSULTED

Abbott, Elizabeth. 1988. Haiti. New York: Simon and Schuster.

Adorno, T.W., Else Frenkel-Brunswik, Daniel J. Levinson, and $R$. Nevitt Sanford. 1950. The Authoritarian Personality. New York: W.W. Norton and Company.

Ahoroni, Yair. 1971. "On the Definition of a Multinational Corporation." Quarterly Review of Economics and Business 2 (Autumn): 3-20.

Apter, David E. and Louis Wolf Goodman (eds). 1976. The Multinational Corporation and Social Change. New York: Praeger.

Argyle, Michael. 1989. The Social Psychology of Work (2nd ed.). New York: Penguin Books.

Aron, Raymond. (1965) 1968. Main Currents in Sociological Thought, Vol. I \& II. (Richard Howard and Helen Weaver, Trans.) Garden City, NY: Anchor Books.

Banaji, Jairus and Rohini Hensman. 1990. Beyond Multinationalism. Newbury Park, CA: Sage.

Barclay, Glen St. John. 1972. 20th Century Nationalism. New York: Praeger.

Benson, John. 1992, March 27. "The glue of shared values still holds." The Christian Science Monitor, pg. 11.

Bergsten, C., T. Horst, and T. Moran. 1978. American Multinationals and American Interests. Washington: Brookings .

Bezirganian, Steve. 1993. "U.S. Affiliates of Foreign Companies: Operations in 1991." Survey of Current Business 73,5 : 89-112.

Blake, David H. and Robert E. Driscoll. 1982. "Perceptions of U.S. Paper Firms in Brazil," in Fayerweather (ed) Host National Attitudes Toward Multinational Corporations (pg. 183-204). New York: Praeger. 
Bodenhausen, Galen V., Lisa Gaelick, and Robert S. Wyer, Jr. 1987. "Affective And Cognitive Factors in Intragroup and Intergroup Communication," in Hendrick (ed) Group Processes and Intergroup Relations (pg. 137-166). Newbury Park, CA: Sage.

Bonacich, Edna. 1980. "Advanced Capitalism and Black/White Race Relations in the United States: A split labor market interpretation," in Pettigrew (ed) The Sociology of Race Relations (pg. 341-362). New York: The Free Press.

Bottomore, T.B. 1973. "Classes in the Industrial Societies," in Chambliss (ed) Sociological Readings in the Conflict Perspective (pg. 85-109). Reading, MA: Addison-Wesley.

Bradshaw, York W. 1988. "Reassessing Economic Dependency and Uneven Development: The Kenyan experience." American Sociological Review 53, 5: 693-708.

Bradsher, Keith. 1993, January 19. "Industries seek protection as vital to U.S. security." The New York Times, $\mathrm{pg}$. Cl.

Brannigan, Martha. 1990, June 5. "Doing business abroad with fewer restraints." The Wall street Journal, pg. B1.

Braunthal, Gerard. 1977. "West Germany: A balance sheet." Current History 73, 431: 156-159, 182-183.

Brockway, George P. 1993. The End of Economic Man. New York: W.W. Norton and Co.

Burg, Steven L. 1993. "Nationalism redux: through the glass of post-Communist states darkly." Current History 92: 162-166.

The Case Against Free Trade. 1993. San Fransisco: Earth Island Press.

Caves, Richard E. 1982. Multinational Enterprise and Economic Analysis. New York: Cambridge University Press.

Chai, Alan, Alta Campbell, and Patrick J. Spain. 1993. Hoover's Handbook of World Business, 1993. Austin: The Reference Press.

Chambliss, william J. (ed). 1973. Sociological Readings in the conflict Perspective. Reading, MA: AddisonWesley. 
Clark, Gerald. 1965. Canada: The uneasy neighbor. New York: David McKay.

Collins, Randall. 1986. Weberian Sociological Theory. New York: Cambridge University Press.

Cook, Karen S. (ed.) 1987. Social Exchange Theory. Newbury Park, CA: Sage.

Cornelius, Wayne A. 1993, July 12. "Neo-nativists feed on myopic fears; no industrial country is able to keep foreign workers from settling in." Los Angeles Times, pg. B7.

Crichton, Michael. 1992. The Rising Sun. New York: Ballantine.

Crozier, Michel and Erhard Friedberg. 1980. Actors and Systems. (Arthur Goldhammer, Trans.). Chicago: The University of Chicago Press.

Curbing foreign control (editorial). 1992, July 1. Los Angles Times, pg. B6.

Deutsch, Karl Wolfgang. 1969. Nationalism and its Alternatives. New York: Knopf.

Directory of American Firms operating in Foreign countries, Vol. 1. 1991. New York: World Trade Academy Press.

Directory of Foreign Firms operating in the United states, (7th, ed.). 1992. New York: World Trade Academy Press.

Doob, Leonard w. 1964. Patriotism and Nationalism. New Haven, CT: Yale University Press.

Durkheim, Emile. (1912) 1971. "On the Future of Religion," in Thompson and Tunstall (eds) Sociological Perspectives (pg. 441-445). New York: Penguin Books.

Ehrens, Cheryl (ed). 1991. Social Sciences Index, April 1990 to March 1991. New York: The H.W. Wilson Co.

Erikson, Kai and Steven Peter Vallas (eds). 1990. The Nature of Work. New Haven, CT: Yale University Press.

Fayerweather, John (ed). 1982. Host National Attitudes Toward Multinational Corporations. New York: Praeger Press. 
Firebaugh, Glenn. 1992. "Growth Effects of Foreign and Domestic Investment." American Journal of Sociology 98, 1: 105-130.

Forbes, H.D. 1985. Nationalism, Ethnocentrism, and Personality. Chicago: The University of Chicago Press.

Frank, Isaiah. 1980. Foreign Enterprise in Developing countries. Baltimore: John Hopkins University Press.

Friedman, Thomas L. 1992, July 12. "As some nations build, the past devours others." The New York Times, pg. E1.

Gallup, George Horace. 1972. The Gallup Poll: Public Opinion, 1935-1971, Vol III. New York: Random House.

Garvey, John. 1992. "We are all foreigners: religion, nation, and race." Commonweal, 119: 8-9.

Gelb, Leslie H. 1991, July 10. "The dark side of disunity." The New York Times, pg. A15.

Gillmore, Mary Rogers. 1987. "Implications of Generalized Versus Restricted Exchange," in cook, (ed), Social Exchange Theory (pg. 170-189). Newbury Park, CA.: Sage.

Gleckman, Howard. 1990, September 10. "Can Uncle Sam mend this hole in his pocket?" Business Week, pg. 48-49.

Glickman, Norman J. and Douglas P. Woodward. 1989. The New Competitors. New York: Basic Books.

Graham, E. and Krugman P. 1991. Foreign Direct Investment in the United States (2nd ed.). Washington D.C.: Institute for International Economics Press.

Greider, William. 1992, April 16. "Citizen GE: How multinationals like General Electric have seized power in the United States." Rolling Stone, pg. 65-72.

Haas, Gilda. 1985. Plant Closures. Boston: South End Press.

Hancock, R. Kelly. 1980. "The Social Life of the Modern Corporation: Changing resources and forms." The Journal of Applied Behavioral Science 16, 3: 279-298.

Heins, John. 1986, June 2. "Plenty of opportunity to fool around." Forbes, pg. 139-140. 
Hendrick, Clyde (ed). 1987. Group Processes and

Intergroup Relations. Newbury Park, CA: Sage.

Hilzenrath, David S. 1993, March 30. "Tackling a multinational muddle; foreign companies prove an elusive tax target for Clinton." The Wall street Journal, pg. Dl.

Hoagland, Jim. 1992, March 17. "All about jobs." The Washington Post, pg. A17.

Hobsbawn, Eric. 1991. "The perils of new nationalism." The Nation 253: pg. 537-538.

Hogg, Michael A. and Dominic Abrams. 1988. Social Identifications. New York: Routledge.

Horowitz, Irving Louis. 1964. Revolution in Brazil. New York: E.P. Dutton and Co., Inc.

Hughes, Cherrington Everett. 1958. Men and Their Work. Giencoe, IL: The Free Press.

Joffe, Josef. 1990. "What just happened: a lite history. This will be a test." The New Republic 203: 18-20.

Jones, walter s. 1991. The Logic of International Relations (7th ed.). New York: Harpercollins.

Kageyama, John A. 1989. "Japanese Managers and American Employees." Pacific Northwest Executive, July: 37.

Kearl, James R. 1993. Principles of Economics. Lexington, MA: D.C. Heath and Company.

Keatley, Robert. 1991, November 7. "NATO gains new life as Europe faces rising threat of nationalism." The Wall street Journal, pg. F2.

Kedourie, Elie. 1961. Nationalism. London: Hutchinson.

Kennedy, Paul. 1987. The Rise and Fall of the Great powers. New York: Vintage Books.

Kis, Danilo. 1992. "Better than our brothers." New Statesman and society 5: 31-32.

Kohn, Melvin L. 1990. "Unresolved Issues in the Relationship Between Work and Personality," in Erikson and Vallas (eds) The Nature of work (pg. 3668). New Haven, CT: Yale University Press. 
Kowalewski, David. 1991. "Core Intervention and Periphery Revolution, 1821-1985." American Journal of Sociology 97,1 : 70-95.

Kujawa, D. 1979. "Collective bargaining and labor relations in multinational enterprise: A U.S. public policy perspective." Research in International Business and Finance Vol. I (pg. 25-61). Greenwich, CT: JAI Press.

Larrain, Jorge. 1989. Theories of Development. Cambridge, MA: Polity Press.

Ladd, Everett. 1986. "Behind the country's high 'gross national spirit'." U.S. News and World Report 101: 16 .

Leone, Bruno (ed.). 1986. Nationalism: Opposing viewpoints. St. Paul, MN: Greenhaven Press.

Levine, Donald N. 1985. The Flight from Ambiguity. Chicago: The University of Chicago Press.

Lewis, Herbert S. 1992, December 28. "Ethnic loyalties are on the rise globally." The christian science Monitor, pg. 18.

Lofland, John. 1977. Doomsday Cult. New York: Halsted Press.

London, Bruce and Thomas D. Robinson. 1989. "The Effects of International Dependence on Income Inequality and political Violence." American Sociological Review 54, 2: 305-308.

Magee, Stephen. P. 1979. "Jobs and the Multinational Corporation: The Home Country Perspective." Research in International Business and Finance, Vol. 1 (pg. 123). Greenwich, CT: JAI Press.

Manning, Steven. 1992. "Nationalism rising." Scholastic Update 125: 2-3.

Marton, Katherin. 1982. "Attitudes Towards Foreign Investments: A case study of the Canadian blue collar worker employed by Ford Canada," in Fayerweather (ed) Host National Attitudes Toward Multinational Corporations, pg. 70-88. New York: Paeger.

Martz, Larry. 1991, April 15. "The corporate shell game: How multinational firms use 'transfer' pricing to evade at least $\$ 20$ billion in U.S. taxes." Newsweek, pg. 48-49. 
Marx, Karl and Friedrich Engels. [1846] 1970. The German Ideology. New York: International Publishers.

-.- [1848] 1972. The Communist Manifesto. New York: Washington Square Press.

Maxcy, George. 1981. The Multinational Automobile Industry. New York: St. Martin's Press.

McGinn, Mary and Kim Moody. 1993. "Labor Goes Global." The Progressive 57, 3: 24-27.

McIntyre, Robert S. 1989, March 27. "Tax Americana: The global tax dodgers." The New Republic, pg. 18-20.

McPhail, Thomas L. 1987. Electronic Colonialism. Newbury Park, CA: Sage.

Meadwell, Hudson. 1989. "Ethnic nationalism and collective choice theory." Contemporary political Studies 22: 139-154.

Melotti, Umberto. 1985. "In-group/Out-group Relations and the Issue of Group selection," in Reynolds, et. al.", The Sociobiology of Ethnocentrism (pg. 94-111). Athens, GA: The University of Georgia Press.

Meyer, Peter. 1985. "Ethnocentrism in Human Social Behavior: Some biosociological considerations," in Reynolds, et. al., The Sociobiology of Enthnoectrism (pg. 81-93). Athens, GA: The University of Georgia Press.

Moran, T. (ed.) 1985. Multinational Corporations. Lexington, MA: D.C. Heath.

Morris, Desmond. 1967. The Naked Ape. New York: Dell.

Moskowitz, Daniel B. 1991, December 23. "Multinationals find ways to make the most of taxing situations." The Washington Post, pg. WB13.

Mueller, Charles W., Jean E. Wallace, and James L. Price. 1992. "Employee Commitment: Resolving some issues." Work and Occupation 19, 3: 211-236.

Murray, J. Alex and Mary C. Gerace. 1972. "Canadian Attitudes Towards U.S. Presence." Public Opinion Quarterly 36,3 : 388-397.

The New York Times Index. 1969-1976. New York: New York Times. 
Nicolaides, Phedon. 1991, May 6. "Rethinking Foreign Investment." Journal of commerce and Commercial, pg. $10 \mathrm{~A}$.

Niosi, Jorge. 1985. Canadian Multinationals. (Robert Chodos, Trans.) Tronto: Between the Lines.

The oregonian. 1992, February 11. "Pickets protest foreign cars," pg. D6.

Oreskes, Michael. 1990, July 10. "Americans voicing anxiety on Japan as concerns in Tokyo seem to soften." The New York Times, pg. All.

Partner, Simon. 1992. Saying Yes to Japanese Investment. Englewood cliffs, NJ: Prentice Hall.

Pascale, Richard Tanner and Anthony G. Athos. 1981. The Art of Japanese Management. New York: Simon and Schuster.

Paulus, Paul B., and Dinesh Nagar. 1987. "Environmental Influences on Social Interaction And Group Development," in Hendrick, (ed) Group Processes and Intergroup Relations (pg. 68-90). Newbury Park, CA: Sage.

Pettigrew, Thomas F. (ed). 1980. The sociology of Race Relations. New York: The Free Press.

Pfaff, William. 1993. The Wrath of Nations. New York: Simon and Schuster.

Piel, Gerard. 1992, May. "Globalopolies." The Nation, pg. 652- 653 .

Pilon, Juliana Geran. 1992. The Bloody Flag. New Brunswick, CT: Transaction Publishers.

Przeworski, Adam and John Sprague. 1986. Paper Stones. Chicago: The University of Chicago Press.

Rex, John and David Mason (eds). 1986. Theories of Race and Ethnic Relations. Cambridge, UK: Cambridge University Press.

Reynolds, V., Vincent S. E. Falger, and Ian Vine (eds). 1985. The Sociobiology of Ethnocentrism. Athens, GA: The University of Georgia Press.

Rothstein, Richard. 1991. "Exporting Jobs and Pollution to Mexico." New Perspectives Quarterly 8, 1: 32-35. 
Sandoval, Salvador A.M. 1993. Social Change and Labor Unrest in Brazil Since 1945. Boulder, CO: Westview.

Sauvant, Karl P. and Bernard Mennis. 1982. "Are there Learning Side-Effects Associated with Employment in a Transnational Business Enterprise?," in Fayerweather (ed) Host National Attitudes Toward Multinational corporations (pg. 275-310). New York: Praeger.

Schermerhorn, R.A. 1978. Comparative Ethnic Relations. Chicago: University of Chicago Press.

Scholl, Russell B., Jeffery H. Lowe, and Sylvia E. Bargas. 1993. "The International Investment Position of the United states in 1992." Survey of Current Business $73,6: \quad 42-55$.

Schrage, Michael. 1992, February 7. "Examining ethnicity and economics." The washington Post, pg. F2.

Seabury, Paul and Angelo Codevilla. 1989. War: Ends and Means. New York: Basic Books.

Senge, Peter M. 1990. The Fifth Discipline. New York: Doubleday Currency.

Shafer, Boyd C. 1955. Nationalism: Myth and Reality. New York: Harcourt, Brace.

Shoumatoff, Alex. 1980. The Capital of Hope. New York: Coward, McCann, and Geoghegam.

Simmel, Georg. [1922] 1955. Conflict and The Web of Group Affiliations. (Reinhard Bendix, Trans.) Glencoe, II: The Free Press.

Sklair, Leslie. 1991. Sociology of the Global system. Baltimore: John Hopkins University Press.

Stahl, walter (ed). 1963. The Politics of Postwar Germany. New York: Praeger.

Tausky, Curt. 1992. "Work is Desirable/Loathsome." Work and eccupations 19, 1: 3-17.

Thompson, Kenneth and Jeremy Tunstall (eds). 1971. sociological Perspectives. New York: Penguin Books.

Thompson, Paul. 1980. The Nature of Work. London: The MacMillan Press, LTD.

Turner, Jonathan H. 1991. The Structure of sociological Theory (5th ed.). Belmont, CA: Wadsworth. 
U.N. (United Nations). 1992. Foreign Direct Investment by Small and Medium-sized Enterprises: Preliminary results of a UN survey. New York: UN Department of Economic and Social Developments.

U.S. attitudes toward foreign investment. 1988. The International Economy, May/June, pg. 28-29.

van den Berghe, Pierre L. 1981. The Ethnic Phenomenon. New York: Elsevier.

van der Dennen, Johan M.G. 1985. "Ethnocentrism and Ingroup/Out-group Differentiation: A review and interpretation of the literature," in Reynolds, et. al., The Sociobiology of Ethnocentrism (pg. 1-47). Athens, GA: The University of Georgia Press.

Van Voorst, Bruce. 1992, June. "Giving away the weapons store." Time, pg. 37.

Wallerstein, Immanuel 1974 : The Capitalist world System. New York: Cambridge University Press.

--- 1991. Geopolitics and Geoculture. New York: Cambrige University Press.

Walsh, w. H. 1975. Kant's Criticism of Metaphysics. Chicago: University of Chicago Press.

walton, John and Charles Ragin. 1990. "Global and National Sources of Political Protest: Third World responses to the debt crisis." American sociological Review 55, 6: 876-890.

Walzer, Michael. 1993. "Between nation and world." The Economist 328: F49-F52.

Ward, Barbara. 1966. Nationalism and Ideology. New York: Norton.

wilkie, James W. (ed). 1980. Statistical Abstracts of Latin America, Vol. 20. San Fransisco: University of California Press.

wimberly, Dale w. 1990. "Investment Dependence and Alternative Explanations of Third World Mortality: A cross-national study." American Sociological Review 55, 1: 75-91.

Wolff, Robert Paul. 1984. Understanding Marx. Oxford, UK: Basil Blackwell.

World Bank Atlas, 1969-1981. Washington D.C.: The World Bank. 
Zakheim, Dov S. 1990, June 27. "Japan's emerging military-industrial machine." The New York Times, pg. A19, 23.

Zdravomyslov, A.G., V.P. Rozhin, and V.A. Iadov (eds). 1970. Man and His Work. (Stephen P. Dunn, Trans.). White Plains, NY: International Arts and Sciences Press. 